ASSESSMENT OF GROUND-WATER CONTAMINATION FROM A

LEAKING UNDERGROUND STORAGE TANK AT A DEFENSE SUPPLY

CENTER NEAR RICHMOND, VIRGINIA

by Winfield G. Wright and John D. Powell

U.S. GEOLOGICAL SURVEY

Water-Resources Investigations Report 90-4091

Prepared in cooperation with

U.S DEPARTMENT OF DEFENSE, DEFENSE GENERAL SUPPLY CENTER

Richmond, Virginia

1990 
DEPARTMENT OF THE INTERIOR

MANUEL LUJAN, JR., Secretary

U.S. GEOLOGICAL SURVEY

Dallas L. Peck, Director

For additional information write to:

Chief, Virginia Office

U.S. Geological Survey

3600 West Broad Street, Room 606

Richmond, Virginia 23230
Copies of this report can be purchased from:

U.S. Geological Survey

Books and Open-File Reports Section

Box 25425, Federal Center, Bldg. 810

Denver, Colorado 80225 


\section{CONTENTS}

Page

Abstract

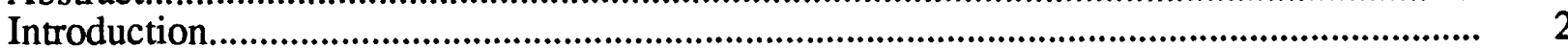

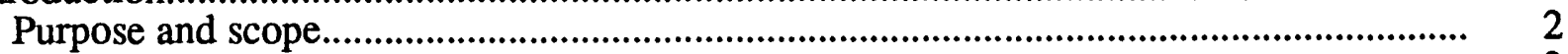

Description of site................................................................................................

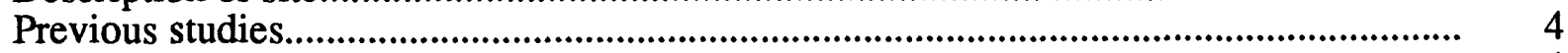

Physical setting.................................................................................................................... 4

Geographic setting.......................................................................................................................

Hydrogeology.........................................................................................................................

Hydrogeologic framework..................................................................................................... 4

Ground-water hydrology........................................................................................... 8

Ground-water use ................................................................................................................ 12

Surface water and subsurface conduits.................................................................. 12

Description of assessment program ............................................................................................ 12

Design of field-study program........................................................................................ 12

History of release and characteristics of contaminants....................................................... 14

Implementation of field study and summary of field work..................................................... 15

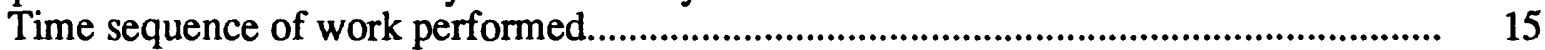

Monitoring-well design and installation............................................................................. 16

Surveying................................................................................................................. 18

Health and safety plan........................................................................................................... 18

Ground-water sampling and quality-assurance program........................................................ 19

Assessment of ground-water contamination......................................................................... 22

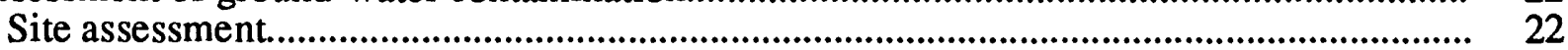

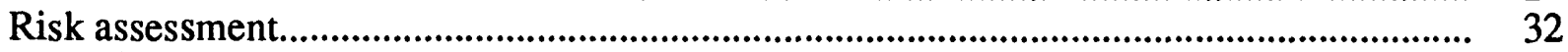

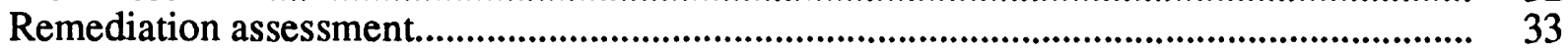

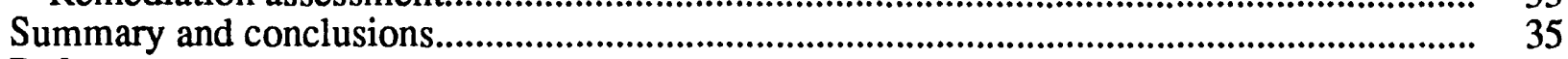

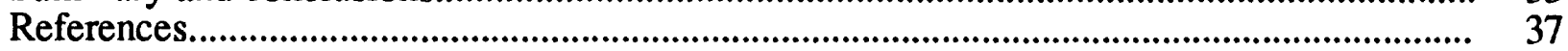

Appendix A: Records of wells at the Defense General Supply Center PX Service Station... 38

\section{ILLUSTRATIONS}

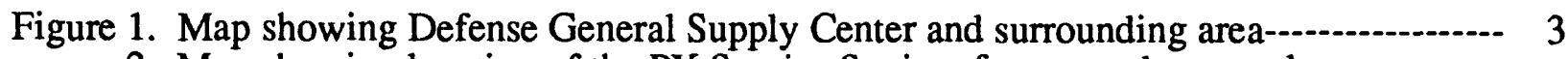

2. Map showing location of the PX Service Station, former underground

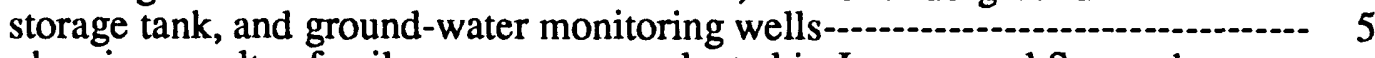

3. Map showing results of soil-gas surveys conducted in January and September 1988 indicating benzene vapors in the unsaturated zone-.........-..- 6

4. Hydrogeologic framework in the vicinity of the PX Service Station-..-.-.-.-.-.-.--- 7

5. Map showing water-level altitudes and inferred direction of ground-water flow, October 27, 1989-

6. Map showing saturated thickness of water-bearing zone in upper aquifer, October 1989-

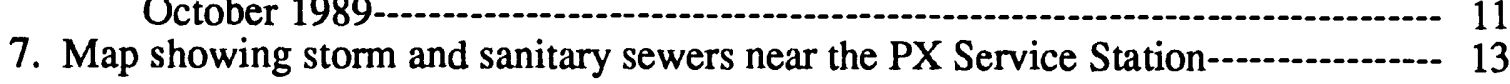


8. Diagram showing construction features of monitoring wells installed at the PX Service Station by the U.S. Geological Survey--.-.-.-.

9. Map showing concentrations of total benzene, toluene, and xylenes

in water from wells at the PX Service Station, May 1989------
10. Map showing concentrations of total benzene, toluene, and xylenes in water from wells at the PX Service Station, September-October 1989------ 28

11. Map showing concentrations of benzene in water from wells at the PX Service Station, September-October 1989

12. Map showing concentrations of toluene in water from wells at the PX Service Station, September-October 1989

13. Map showing concentrations of total xylenes in water from wells at the PX Service Station, September-October 1989

\section{TABLES}

Table 1. Aquifer characteristics at the Defense General Supply Center

2. Chronology of field investigations at the PX Service Station-

3. Types and dates of water samples collected and field-data measurements of $\mathrm{pH}$, specific conductance, temperature, and dissolved oxygen, May 1989-

4. Types and dates of water samples collected and field-data measurements of $\mathrm{pH}$, specific conductance, temperature, and dissolved oxygen, September-October 1989.

5. Analytical constituents and reporting limits for analysis of soil and ground-water samples at the PX Service Station-

6. Concentrations of total petroleum hydrocarbons in water from wells in the vicinity of the former leaking tank, July 1988

7. Concentrations of benzene, toluene, xylene, and total BTX compounds in water from wells at the PX Service Station, May 1989.

8. Concentrations of benzene, toluene, xylene, and total BTX compounds in water from wells at the PX Service Station, September-October 1989-...-.-.

9. Concentrations of compounds other than BTXs identified in water from wells at the PX Service Station, May 1989

10. Compounds tentatively identified in water from wells at the PX Service Station

11. Exposure-point concentrations of indicator chemicals in water from well PX-12 compared to applicable, relevant, and appropriate requirements defined for these compounds- 


\section{CONVERSION FACTORS AND ABBREVIATIONS}

The following factors may be used to convert inch-pound units to metric (International System) units.

\begin{tabular}{|c|c|c|}
\hline Multiply inch-pound units & By & To obtain metric unit \\
\hline $\begin{array}{l}\text { inch (in.) } \\
\text { foot }(\mathrm{ft}) \\
\text { mile (mi) }\end{array}$ & $\begin{array}{l}\frac{\text { Length }}{25.4} \\
0.3048 \\
1.609\end{array}$ & $\begin{array}{l}\text { millimeter }(\mathrm{mm}) \\
\text { meter }(\mathrm{m}) \\
\text { kilometer }(\mathrm{km})\end{array}$ \\
\hline $\begin{array}{l}\text { square mile }\left(\mathrm{mi}^{2}\right) \\
\text { square mile }\left(\mathrm{mi}^{2}\right)\end{array}$ & $\begin{array}{l}\frac{\text { Area }}{2.590} \\
259.0\end{array}$ & $\begin{array}{l}\text { square kilometer }\left(\mathrm{km}^{2}\right) \\
\text { hectare (ha) }\end{array}$ \\
\hline $\begin{array}{l}\text { gallon (gal) } \\
\text { cubic foot }\left(\mathrm{ft}^{3}\right)\end{array}$ & $\begin{array}{l}\text { Volume } \\
3.785 \\
0.02832\end{array}$ & $\begin{array}{l}\text { liter }(\mathrm{L}) \\
\text { cubic meter }\left(\mathrm{m}^{3}\right)\end{array}$ \\
\hline $\begin{array}{l}\text { cubic foot per second } \\
\qquad\left(\mathrm{ft}^{3} / \mathrm{s}\right) \\
\text { gallon per minute (gal/min) }\end{array}$ & $\begin{array}{l}\frac{\text { Flow }}{0.02832} \\
0.06308\end{array}$ & 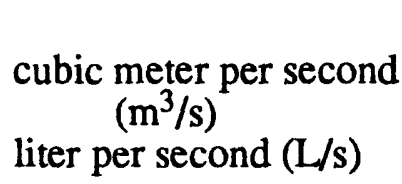 \\
\hline
\end{tabular}

Chemical concentration, temperature, and specific conductance are given in metric units. Chemical concentration is expressed in milligrams per liter $(\mathrm{mg} / \mathrm{L})$. Temperature in degrees Celsius $\left({ }^{\circ} \mathrm{C}\right)$ can be converted to degrees Fahrenheit $\left({ }^{\circ} \mathrm{F}\right)$, and vice versa, as follows:

$$
\begin{aligned}
& { }^{\circ} \mathrm{F}=\left(1.8 \times{ }^{\circ} \mathrm{C}\right)+32 \\
& { }^{\circ} \mathrm{C}=\left({ }^{\circ} \mathrm{F}-32\right) \times 0.5555
\end{aligned}
$$

Specific conductance is expressed in microsiemens per centimeter (us $/ \mathrm{cm})$ at 25 degrees Celsius.

Sea level: In this report "sea level" refers to the National Geodetic Vertical Datum of 1929 (NGVD of 1929)-- a geodetic datum derived from a general adjustment of the first-order level nets of both the United States and Canada, formerly called "Sea Level Datum of 1929." 


\title{
ASSESSMENT OF GROUND-WATER CONTAMINATION FROM A LEAKING UNDERGROUND STORAGE TANK AT A DEFENSE SUPPLY CENTER NEAR RICHMOND, VIRGINIA
}

\author{
By Winfield G. Wright and John D. Powell
}

\begin{abstract}
During 1988-89, 24 wells were installed in the vicinity of the post-exchange gasoline station (PX Service Station) on the Defense General Supply Center, near Richmond, Virginia, to collect and analyze ground-water samples for the presence of gasoline contamination from a leaking underground storage tank. The monitoring wells were installed in shallow aquifers composed of unconsolidated Coastal Plain sediments that are configured, from top to bottom, as an upper aquifer, confining unit, and lower aquifer. Analyses of ground water from monitoring wells in the upper aquifer indicate concentrations of total petroleum hydrocarbons as large as 8.2 milligrams per liter in the immediate vicinity of the former tank and concentrations of total BTXs (or the sum, in micrograms per liter, of benzene, toluene, and xylenes) as large as $83,000 \mu \mathrm{g} / \mathrm{L}$ (micrograms per liter). Concentrations of BTXs in water samples from monitoring wells on the periphery of the site were below reporting limits. Between the May 1989 and September-October 1989 sampling rounds, concentrations of total BTXs in water from the monitoring wells increased in some wells and decreased in other wells.
\end{abstract}

Organic vapors were detected in samples of the confining unit collected during drilling. Concentrations of BTXs in water from the one well in the lower aquifer totalled $41.4 \mu \mathrm{g} / \mathrm{L}$ in May 1989 and were below reporting limits in the second and third samples collected from the same well in September and October 1989.

Water-level data from monitoring wells in the vicinity of the PX Service Station indicate ground water in the upper aquifer flows to the east-southeast. Ground-water-flow rates in the upper aquifer are estimated to be approximately 60 to 80 feet per year. Ground water contaminated with BTXs might infiltrate a subsurface storm sewer, where the storm sewer is below the water table, and discharge through the sewer into a nearby stream.

The available analyses from the monitoring wells at the PX Service Station indicate that the contaminant plume in the upper aquifer is oriented along the direction of ground-water flow (to the east-southeast); however, the plume is widespread in nature and extent of the plume has not been well defined. The presence of benzene $(2,300 \mu \mathrm{g} / \mathrm{L})$ in water from a well located 600 feet downgradient from the PX Service Station suggests that the contaminants might have entered the ground water 7 to 10 (or more) years ago.

Risk assessment for the site identified no potential human receptors to the ground-water contamination because no ground-water users were identified in the area. The largest concentrations of contaminants at the site exceed Federal maximum contaminant levels for drinking water by as much as a factor of 5,000; remediation may be appropriate if exposure of future potential receptors is a concern.

Possible alternative actions discussed for remediation of ground-water contamination in the upper aquifer at the PX Service Station include no action, soil-vapor extraction, and ground-water pumping and treatment. The soil-vapor-extraction method is the favored remedial alternative because of the widespread nature of the plume. Existing monitoring wells could be 
used for installation of soil-vapor-extraction pumps that could promptly apply remedial measures. Insufficient water depths in the upper aquifer limit the efficiency of the pumping scheme alternative. Continued monitoring is needed to verify the results presented in this report.

\section{INTRODUCTION}

In May 1987, the Defense General Supply Center (DGSC), near Richmond, Virginia (fig. 1), discovered, by examining inventory data, that as much as 4,000 gallons of premium unleaded gasoline may have leaked out of an underground storage tank at the post-exchange service station (PX Service Station). The Virginia Water Control Board (VWCB) was notified and, subsequently, a monitoring well was installed approximately 10 feet from the tank. The presence of gasoline vapors within the well casing was verified by an organic-vapor detector. The leaking tank was subsequently removed. Because of experience with previous studies at the DGSC (Powell and others, written commun., 1987), the U.S. Geological Survey was contacted to install ground- water monitoring wells in the area around the PX Service Station and, at a later date, to install additional wells and assess the ground-water contamination problem.

In June 1988, the U.S. Geological Survey installed seven ground-water monitoring wells (hereafter called the initial wells) in the vicinity of the PX Service Station. In May 1989, the Survey installed 11 additional ground-water monitoring wells (hereafter called the exploratory wells) downgradient from the PX Service Station in order to determine the general concentrations and distribution of contaminants and potential directions of migration. In September 1989, six additional monitoring wells (hereafter called the confirmatory wells) were installed downgradient of the initial and exploratory wells to define the downgradient extent of the contamination.

\section{Purpose and Scope}

This report documents the efforts of the U.S. Geological Survey to describe the ground-water contamination at the PX Service Station at the Defense General Supply Center (DGSC), near Richmond, Virginia. The report presents preliminary site, risk, and remediation assessments, which include information on the hydrogeology, ground water, surface water, water use, characteristics and release of the contaminants, and occurrence of subsurface conduits (storm and sanitary sewers) in the vicinity of the study area. The risk assessment identifies possible receptors to the contamination and discusses concentrations of contaminants reported in the ground water. The remediation assessment discusses the need and feasibility of remediation of the contaminated ground water. Plausible alternative technologies to remediate the site are identified.

Hydrologic and geologic data and water samples were collected during 1988-89 from wells completed in the vicinity of the PX Service Station on the DGSC. Water samples were analyzed for concentrations of petroleum hydrocarbons and purgeable-organic compounds. Temperature, $\mathrm{pH}$, specific conductance, and dissolved-oxygen concentrations in ground water were measured in the field. Soil samples were analyzed for petroleum hydrocarbons.

\section{Description of Site}

The DGSC (fig. 1), constructed during 1941-42, serves as a depot for general supplies for the Department of Defense. The DGSC is located in Chesterfield County, Virginia, about 5 miles south of the city of Richmond, Virginia, and occupies an area of about 1 square mile.

The study area covers about 30 acres around the PX Service Station, and includes streets, 


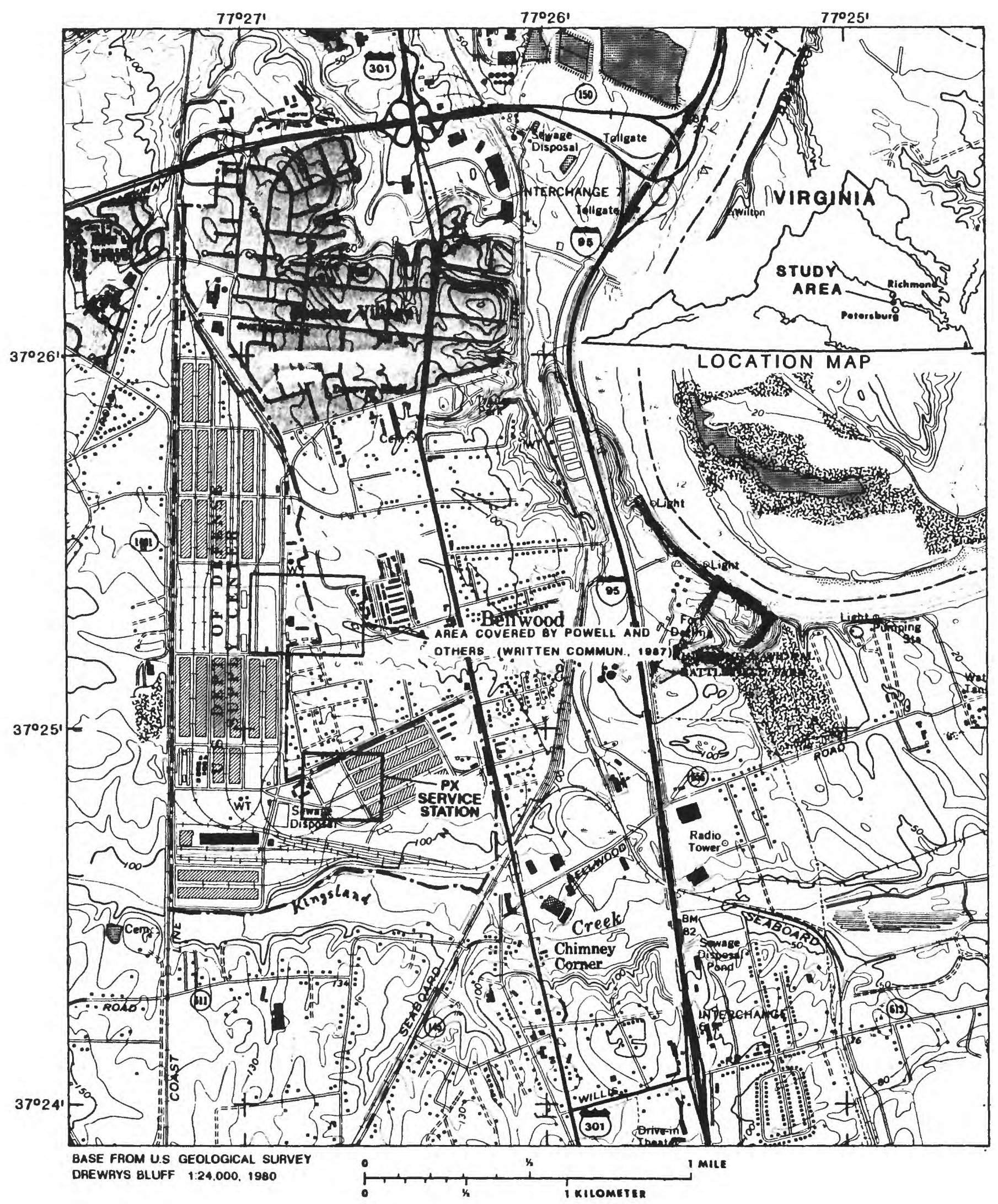

Figure 1.--Defense General Supply Center and surrounding area. 
parking lots, small grassy areas, and railroad tracks (fig. 2). The terrain consists mostly of level parking areas and gentle slopes resulting from excavations during construction of the installation. In addition to the tank removed after discovery of a leak, three other underground storage tank fields are located at the PX Service Station (fig. 2).

\section{Previous Studies}

Several studies relating to ground-water contamination have been conducted at the DGSC. Most of these studies relate to ground-water contamination resulting from improper solvent waste-disposal practices of the 1950's and 60's. Powell and others (written commun., 1987) documented the efforts of the U.S. Geological Survey during 1984-87 to investigate ground-water contamination east of the installation boundary in the vicinity of a landfill and a National Guard Area located north of the PX Service Station on the DGSC (fig. 1). The hydrogeologic framework of the DGSC defined during this study serves as a basis for the framework defined for the PX Service Station study area.

Two soil-gas studies were conducted in the vicinity of the former underground storage tank at the PX Service Station (Target Environmental Services, 1988a; 1988b). These soil-gas studies confirmed the presence of benzene vapors in the unsaturated zone to the east-southeast and west of the former tank location (fig. 3). Organic vapors were not detected in large concentrations in the immediate vicinity of the former tank presumably because the vapors had volatilized from the tank-excavation hole. Organic vapors in the ground were detected as far as 200 feet to the southeast of the former tank location.

\section{PHYSICAL SETTING}

\section{Geographic Setting}

The DGSC is located on the western edge of the eastward-thickening wedge of unconsolidated sediments of the Virginia part of the Atlantic Coastal Plain physiographic province, about 2 miles east of the Fall Line. The area around the PX Service Station has land-surface elevations ranging from approximately 120 to 130 feet above sea level. The area is covered mostly by asphalt parking lots and streets. The moderate topographic relief is the result of shallow excavations and filling for the construction of the DGSC. The northern part of the DGSC drains toward an unnamed creek east of the DGSC; the southern part drains toward Kingsland Creek (fig. 1). Both creeks are tributaries of the James River.

\section{Hydrogeology}

\section{Hydrogeologic Framework}

A hydrogeologic framework was developed for the DGSC area by Powell and others (written commun., 1987) using data from lithologic logs, geophysical logs, and core samples. This framework, consistent with information obtained at the PX Service Station, is comprised of an upper aquifer (Yorktown and Eastover Formations), a confining unit (the Calvert and Aquia Formations), and a lower aquifer (Potomac Formation) (fig. 4). Bedrock (Petersburg Granite) underlies the Potomac Formation.

The upper aquifer is composed of alluvial sediments of the Pliocene Yorktown Formation and Miocene Eastover Formation. This aquifer differs in color, lithology, and thickness over the DGSC but generally remains uniform in the vicinity of the PX Service Station. It is rust to orange in color and is a clayey to silty, fine- to medium-grained sand. It contains a basal sand, gravel, and cobble layer. The basal layer, which directly overlies the Calvert 

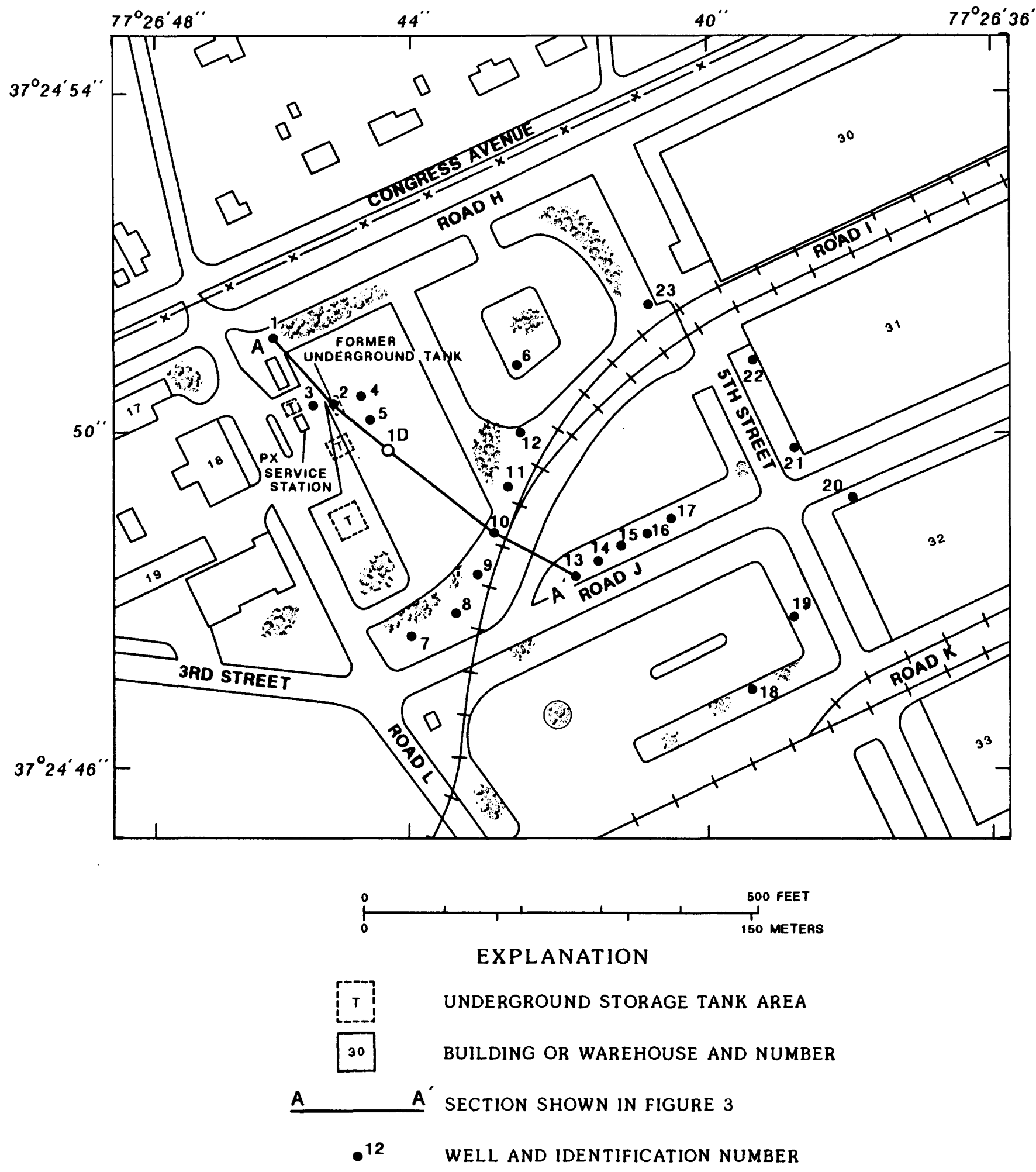

Figure 2.--Location of the PX Service Station, former underground storage tank, and ground-water monitoring wells. 

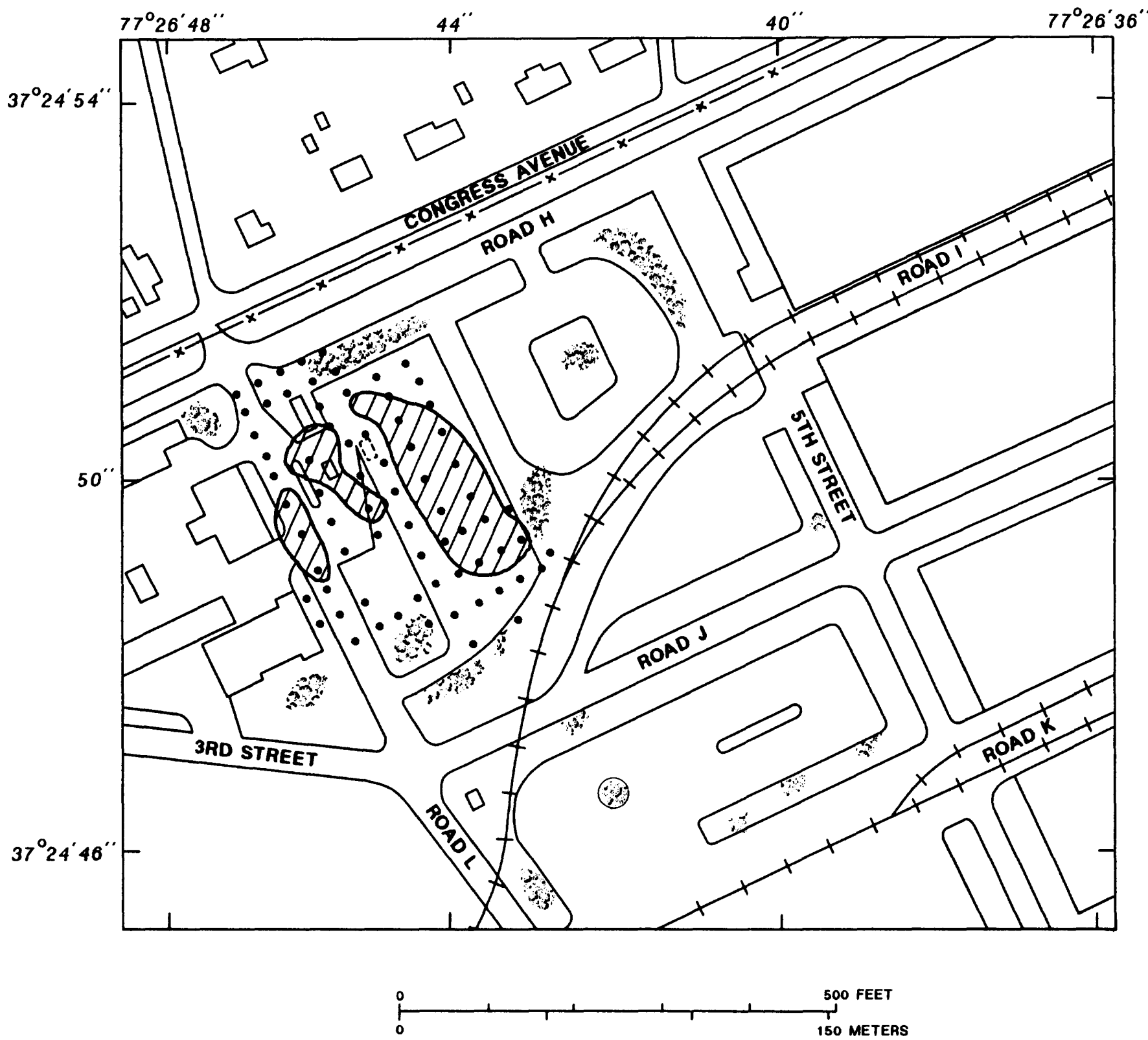

EXPLANATION

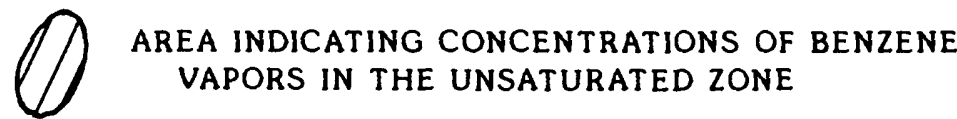

- SOIL-GaS SAMPLING LOCATION

Figure 3.--Results of soil-gas surveys conducted in January and September 1988 indicating benzene vapors in the unsaturated zone (modified from Target Environmental Services, 1988a, 1988b). 

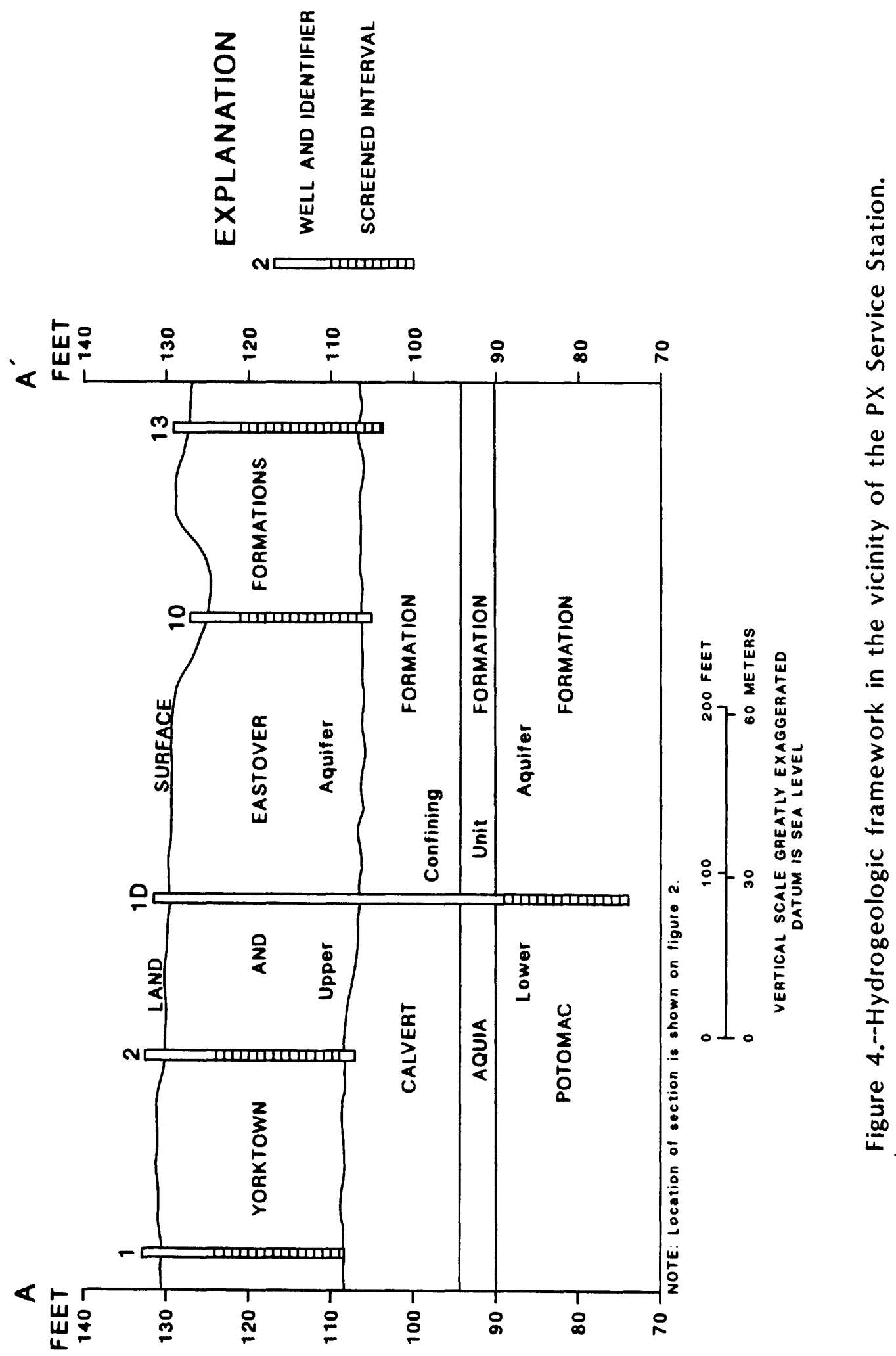
Formation, is present in many locations throughout the DGSC (Powell and others, written commun., 1987). A sand layer is present at an altitude of about 106 to $110 \mathrm{ft}$ (feet) above sea level (20-25 ft below land surface) in the vicinity of the PX Service Station. This sand layer was not always observed in wells drilled in other areas of the DGSC.

The confining unit is composed of marine sediments of the Calvert and Aquia Formations. The Miocene Calvert Formation is a dark grey deposit of silt, fine sand, and clay. The base of this formation consists of clay intermixed with sand and gravel and contains shark teeth and wood fragments (Powell and others, written commun., 1987). The Paleocene Aquia Formation is a fining-upward, well-sorted, dark green, glauconitic sand with a basal gravel stratum. The thickness of the confining unit in the vicinity of the PX Service Station is approximately $15 \mathrm{ft}$.

The lower aquifer is composed of alluvial sediments of the Cretaceous Potomac Formation. This formation is greyish-green, medium- to very-coarse grained sand and gravel interbedded with clay layers. The thickness of this unit ranges from approximately 25 to $40 \mathrm{ft}$ throughout the DGSC (Powell and others, written commun., 1987).

The depth to the Mississippian Petersburg Granite at the PX Service Station was not determined during drilling. It is estimated to be at a depth of about 60 to $80 \mathrm{ft}$ below land surface, based on data from Powell and others (written commun., 1987).

The aquifers and confining units at the PX Service Station are at the western edge of a eastward-thickening wedge of sediments comprising the aquifers and intervening confining units of the Coastal Plain physiographic province. Examination of the complete stratigraphic column of the Coastal Plain hydrogeologic framework (Meng and Harsh, 1988), defined at its thickest point (about 4,000 ft below land surface at the Chesapeake Bay), indicates that the St. Mary's, Choptank, Old Church, Chickahominy, Piney Point, Nanjemoy, Marlboro, and Brightseat Formations are absent in the DGSC area of the western edge of the Coastal Plain. The aquifers present at the study site, however, are continuous units from the study site eastward; for example, sediments of the Potomac Formation range from 35 to $70 \mathrm{ft}$ below land surface at the study site and extend eastward to great depths, uninterupted by confining units over the entire eastward extent.

\section{Ground-Water Hydrology}

Water-level data were collected on October 27, 1989, and are shown in figure 5. From these water levels, the inferred direction of ground-water flow in the upper aquifer at the site is to the east-southeast. The direction of ground-water movement in the lower aquifer is not known because only one well was installed in the lower aquifer.

Hydraulic conductivity, porosity, and hydraulic gradient control the average-linear velocity of ground water, which approximates the linear travel distance of ground water per unit of time. Aquifer and confining-unit characteristics, including hydraulic conductivities, were determined by aquifer tests performed by Powell and others (written commun., 1987); results are shown in table 1 . It is possible, however, that the hydraulic characteristics in the vicinity of the PX Service Station differ slightly from those determined by Powell and others (written commun., 1987). 

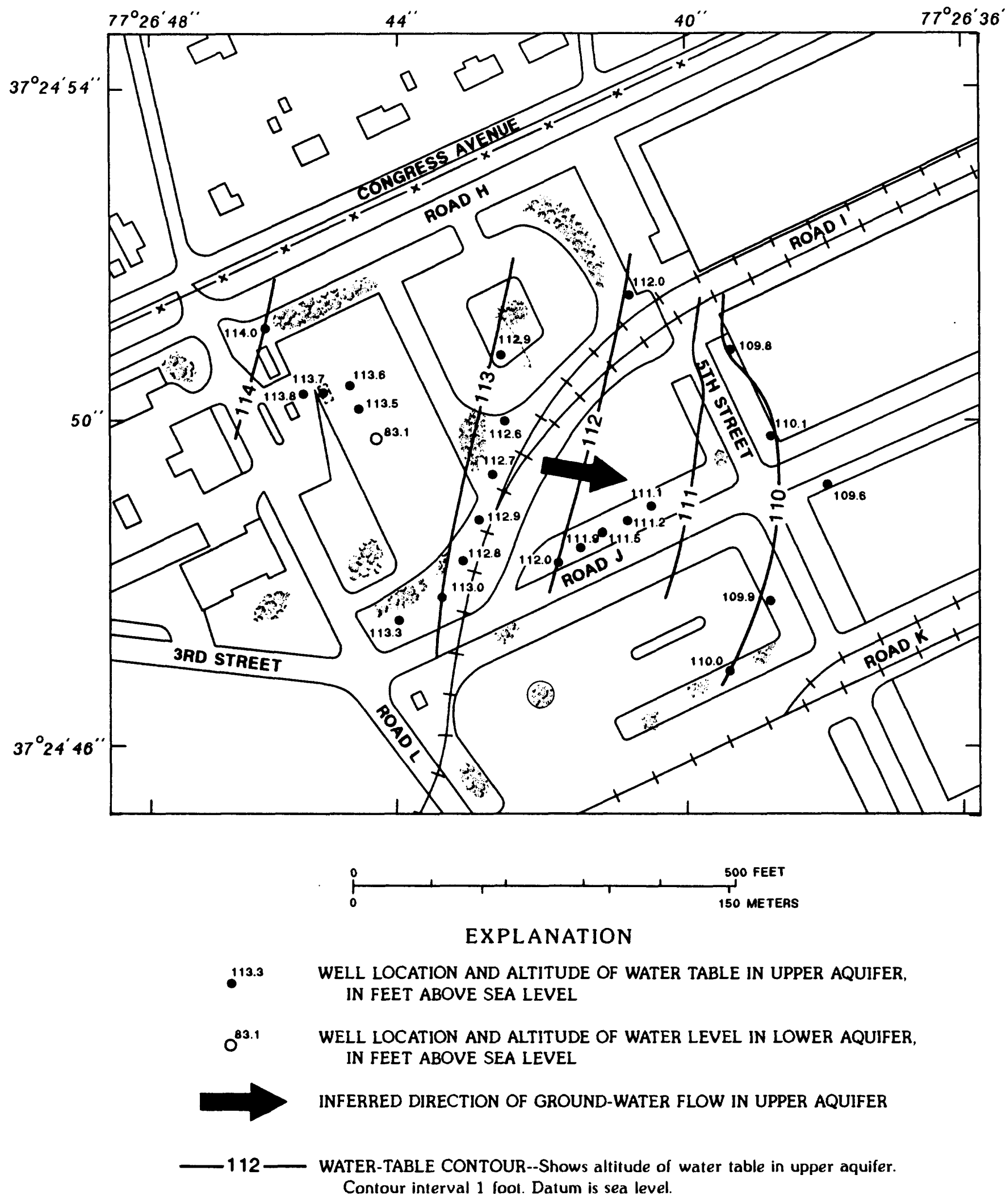

Figure 5.--Water-level altitude and inferred direction of ground-water flow in the upper aquifer, October 27, 1989. 


\begin{tabular}{|c|c|c|c|c|c|}
\hline \multicolumn{6}{|c|}{$\begin{array}{l}\text { (Modified from Powell and others (written commun., } 1987, \text { table } 3 \text { ), } T= \\
\text { transmissivity, in feet squared per day; } K_{h}=\text { horizontal } \\
\text { hydraulic conductivity, in feet per day; } K_{r}=v e r t i c a l \\
\text { hydraulic conductivity, in feet per day; } s=\text { storage coefficient, } \\
\text { dimensionless; "-" = unknown value) }\end{array}$} \\
\hline Formation & $\begin{array}{c}\text { Hydrogeologic } \\
\text { unit }\end{array}$ & $\boldsymbol{x}$ & $K_{b}$ & $\boldsymbol{K}_{\mathbf{r}}$ & $s$ \\
\hline $\begin{array}{l}\text { Yorktown and } \\
\text { Eastover }\end{array}$ & $\begin{array}{l}\text { Upper } \\
\text { aquifer }\end{array}$ & 90 & 6 & -- & $1 \times 10^{-2}$ \\
\hline Calvert & $\begin{array}{l}\text { Confining } \\
\text { unit }\end{array}$ & -- & -- & $2.7 \times 10^{-4}$ & -- \\
\hline Aquia & $\begin{array}{l}\text { Confining } \\
\text { unit }\end{array}$ & $3.5 \times 10^{-2}$ & $5 \times 10^{-3}$ & $5 \times 10^{-3}$ & $2 \times 10^{-0}$ \\
\hline Potomac & $\begin{array}{l}\text { Lower } \\
\text { aquifer }\end{array}$ & 275 & 18 & 2 & $2 \times 10^{-5}$ \\
\hline
\end{tabular}

The average linear velocity of the ground water can be estimated using the horizontal hydraulic conductivity for the upper aquifer shown in table 1 , an estimate for porosity, and the hydraulic gradient at the PX Service Station from the October 27, 1989, water-level data as follows:

$$
\mathrm{V}=\frac{\mathrm{Kh}}{\mathrm{n}} \frac{\mathrm{dh}}{\mathrm{dl}}
$$

where: $\mathrm{V}=$ average linear velocity of ground-water flow,

$\mathrm{Kh}=$ horizontal hydraulic conductivity (table 1 ),

$\mathrm{n}=$ porosity of aquifer ( 0.30 for upper aquifer),

$\underline{\mathrm{dh}}=$ hydraulic gradient (difference in water levels per unit distance

$\mathrm{dl}$ measured between two monitoring wells; ranges from 0.008 to 0.011 in the upper aquifer).

Based on this equation, average linear velocity of ground-water flow in the upper aquifer in the vicinity of the PX Service Station is estimated to be approximately 60 to 80 feet per year.

The thickness of the water-bearing zone in the upper aquifer, based on water-levels measured on October 27, 1989, averages approximately $5.5 \mathrm{ft}$ throughout the study area (fig. $6)$. The saturated thickness of the water-bearing zone changes with seasons because the amount of precipitation, recharge, and evapotranspiration affects the rise and fall of the water table; for instance, the saturated thickness of the water-bearing zone in the upper aquifer in 

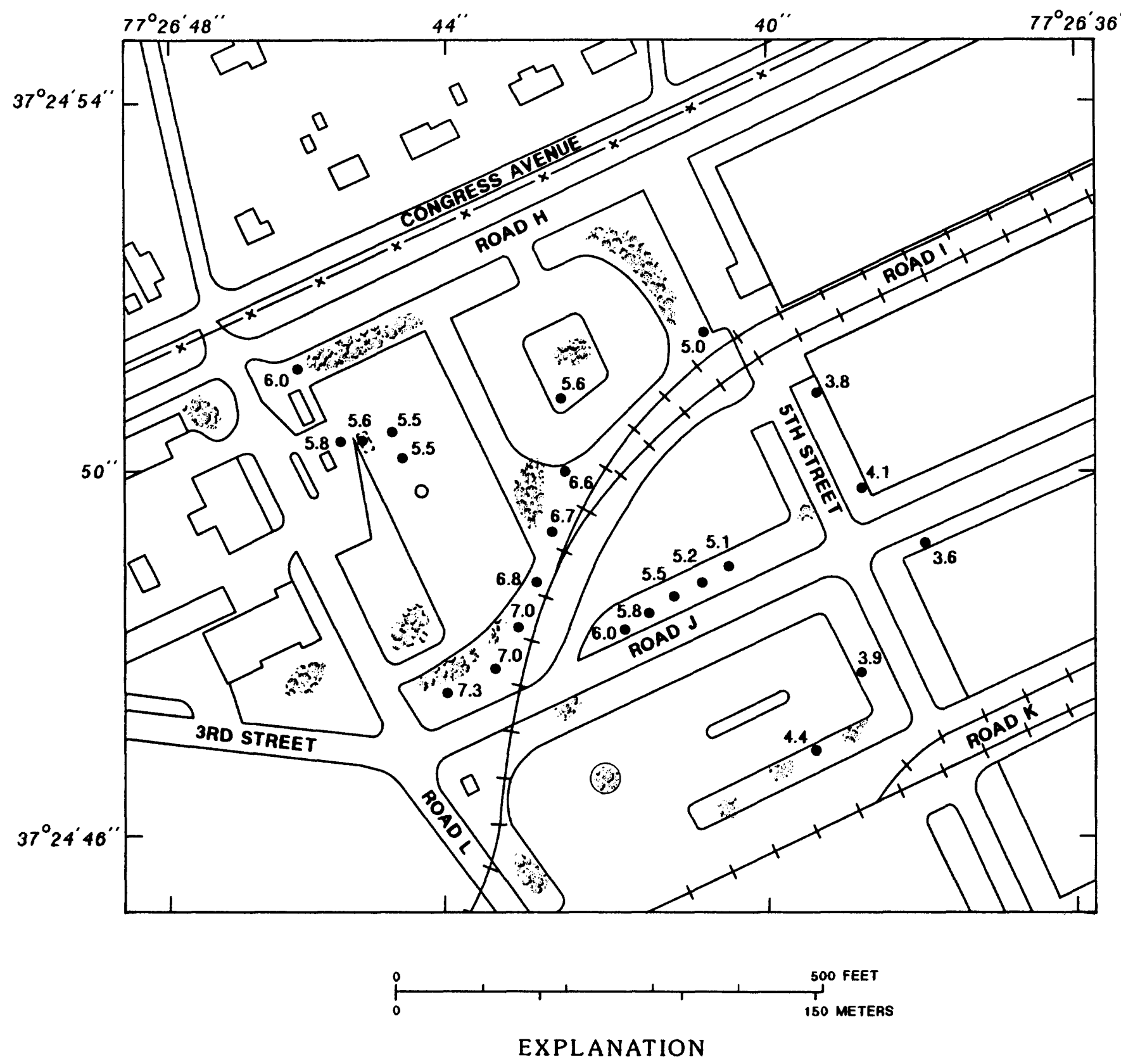

- well location

5.6 SATURATED THICKNESS OF WATER-BEARING ZONE IN UPPER AQUIFER, IN FEET

Figure 6.--Saturated thickness of water-bearing zone in upper aquifer, October 27, 1989. 
June 1989 ranged from 7 to $8 \mathrm{ft}$.

The water-level in the lower-aquifer well (PX-1D) was $83.1 \mathrm{ft}$ above sea level on October 27,1989 (fig. 5). This altitude is about $7 \mathrm{ft}$ lower than the 90 - $\mathrm{ft}$ altitude of the bottom of the confining unit (fig. 4). This indicates that the Potomac aquifer is not confined in the vicinity of the PX Service Station, even though the aquifer is confined in areas to the north of the study area (Powell and others, written commun., 1987). The difference between hydraulic heads in the upper aquifer and the lower aquifer indicates a downward hydraulic gradient of about $30 \mathrm{ft}$ between the aquifers.

\section{Ground-Water Use}

Ground-water users nearest the study area are located in the Rayon Park subdivision north of the PX Service Station. Public-water connection was made available to the Rayon Park residents in 1987 and most, if not all, of the residents accepted the public-water service (Defense General Supply Center Installation Services, oral commun., 1988). Several ground-water users are present south of Kingsland Creek. Most of the privately owned wells in the vicinity of the DGSC have been tested because of ground-water quality concerns unrelated to this report; most of the wells are no longer used for private drinking-water supply because of the availability of public water.

\section{Surface Water and Subsurface Conduits}

Kingsland Creek (fig. 1) is the only surface-water feature that potentially could be affected by ground water from the study area. Kingsland Creek is a possible hydrologic boundary where ground-water flow discharges into the creek.

Manmade subsurface conduits exist in the vicinity of the PX Service Station in the form of storm and sanitary sewers (fig. 7). The sanitary sewer lines were installed in the 1940's from approximately 1.5 to to $3 \mathrm{ft}$ below land surface and are constructed of clay pipe ( $R$. Holt, Defense General Supply Center Engineering, oral commun., 1989). Storm sewers were installed at depths ranging from 8 to $15 \mathrm{ft}$ below land surface. These storm sewers drain west to east and north to south in the vicinity of the PX Service Station and collect rainfall, runoff, and water from air-conditioning units which is then discharged into Kingsland Creek (R. Holt, Defense General Supply Center Engineering, oral commun., 1989). The storm sewers, where constructed below the water table, may also collect ground water from the upper aquifer. Sufficient data do not exist to quantify infiltration of ground water into the storm sewer if such infiltration occurs.

\section{DESCRIPTION OF ASSESSMENT PROGRAM}

\section{Design of Field-Study Program}

The field-study program was designed to place monitoring wells on the periphery of the site to determine background ground-water quality, to provide water-level data to estimate ground-water flow directions, and to place monitoring wells in the vicinity of the former tank and downgradient of the site to document ground-water quality. Ground-water samples collected from the monitoring wells were analyzed for constituents that are indicators of gasoline contamination.

Water levels in the seven initial wells in June 1988 indicated that ground-water flow direction is south-southeast; therefore, the 10 exploratory wells in the upper aquifer were placed to the south-southeast of the PX Service Station. The expanded set of water-level 

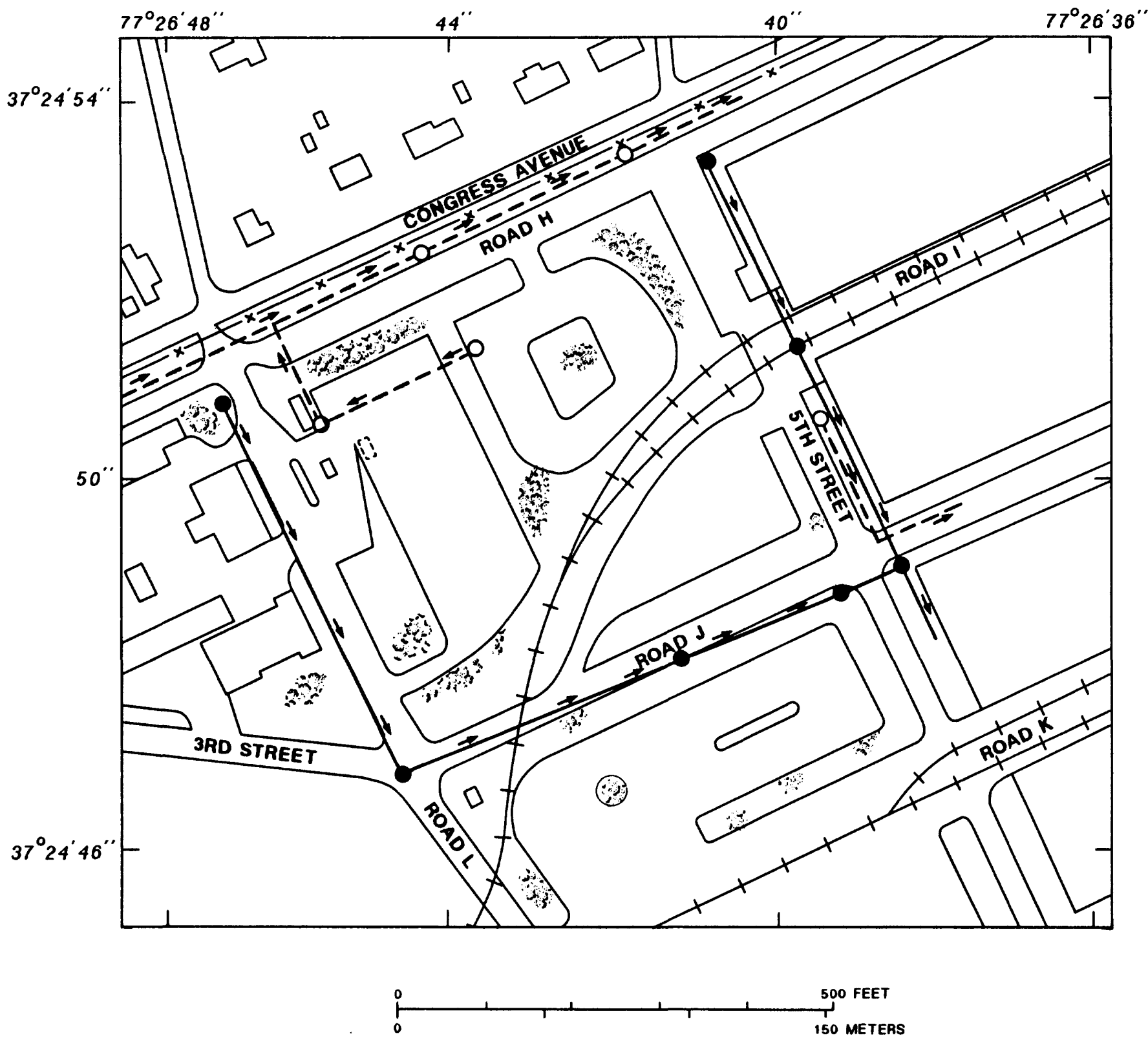

EXPLANATION

$\rightarrow \longrightarrow$ STORM SEWER, MANHOLE OR COLLECTION BOX, AND FLOW DIRECTION

$\rightarrow-0 \rightarrow$ SANITARY SEWER, MANHOLE OR COLLECTION BOX, AND FLOW DIRECTION

Figure 7.--Storm and sanitary sewers near the PX Service Station. 
measurements obtained from 17 wells in the upper aquifer in May 1989 indicated that the actual ground-water flow direction is east-southeast (fig. 5); therefore, the confirmatory wells were placed east-southeast of the site.

\section{History of Release and Characteristics of Contaminants}

In May 1987, the DGSC, near Richmond, Virginia, determined through inventory data that gasoline possibly had leaked from an underground storage tank at the PX Service Station. The VWCB was notified, subsequently the tank was removed, and on May 14, 1987, a monitoring well was installed approximately 10 feet from the tank. Gasoline vapors were detected within the well casing using a organic-vapor detector and gasoline product was observed in the well (W. Saddington, Defense General Supply Center Environmental Engineering, oral commun., 1988).

The date(s) of the release is not known, but an estimated 4,000 gallons of premium-unleaded gasoline were unaccounted for from the former underground storage tank at the PX Service Station. In addition to the known former leaking tank, other underground storage tanks at the PX Service Station are possible sources of ground-water contamination.

The chemical characteristics of the contamination at the PX Service Station are typical of commercial grades of motor gasoline. Commercial-grade gasoline is produced by fractional distillation of petroleum and contains added paraffins, olefins, napthenes, and aromatics, all in substantial concentrations (Merck Index, 1983). Gasoline is produced from the "cracking" of high boiling-point petroleum fractions in the presence of catalysts, whereby complex hydrocarbon molecules are broken down into simpler, but more purgeable, compounds. When mixed with the proper amounts of air, the vapors form a mixture that is highly volatile, readily ignited, and burns with explosive violence. The purgeable-organic components of gasoline are mainly composed of the compounds containing benzene, toluene, and xylene (hereafter termed BTXs).

The BTX compounds are nonpolar and slightly soluble to very insoluble in water. The major processes currently recognized as having significant potential for control of the migration of these compounds in hydrogeologic regimes include sorption, chemical reaction, and biological reaction (Cherry and others, 1984, p. 55). Organic solutes, especially those that are nonpolar and relatively insoluble, tend to be absorbed by sediments and soils. Sorption of organic compounds on mineral surfaces has been documented by field and laboratory research indicating that the sorption of organic compounds is predominantly onto particulate organic matter in the sediments. This partitioning of the solute between the aqueous phase and organic matter generally reaches equilibrium rapidly and is reversible dependent upon the $\mathrm{pH}$ of the aqueous solution. The major mechanisms of chemical transformation or degradation of organic compounds in aqueous systems are photolysis, oxidation, hydrolysis, and reduction; further discussions of chemical transformation of organic compounds can be found in Callahan (1979).

Biological reaction and reduction of organic compounds is probably the most important mechanism for the transformation of BTXs (Alexander, 1981). The presence of oxygen in the hydrogeologic regime is usually necessary for the biotransformation of organic substances; however, studies have been conducted indicating that anaerobic bacteria can also play a role in transformation of organic compounds (Cherry and others, 1984, p. 57). Volatilization may be another control on the removal of purgeable-organic contaminants from ground water. In laboratory experiments with benzene and toluene in stagnant water, Chiou and others $(1983, \mathrm{p}$. 15 ) indicate that about 50 percent of the solute remains in solution after 5 hours at a temperature of $25^{\circ} \mathrm{C}$ (degrees Celcius), a humidity of 40 percent, and an initial concentration of $100 \mathrm{mg} / \mathrm{L}$ (milligrams per liter). 


\section{Implementation of Field Study and Summary of Field Work}

Seventy-six ground-water samples, including samples for quality assurance, were collected from 24 monitoring wells. Twenty-eight soil samples were collected from seven monitoring wells. Four separate water-level measurements were made in all 24 wells to assure the reproducibility of the measurements.

\section{Time Sequence of Work Performed}

The initial phase of the asessment began in June 1988, the exploratory phase began in May 1989 , and the confirmatory phase was completed in October 1989. A chronology of the investigation at the PX Service Station, including tasks accomplished prior to the assessment documented in this report, is provided in table 2 .

Table 2.--Chronology of field investigations at the PX service station

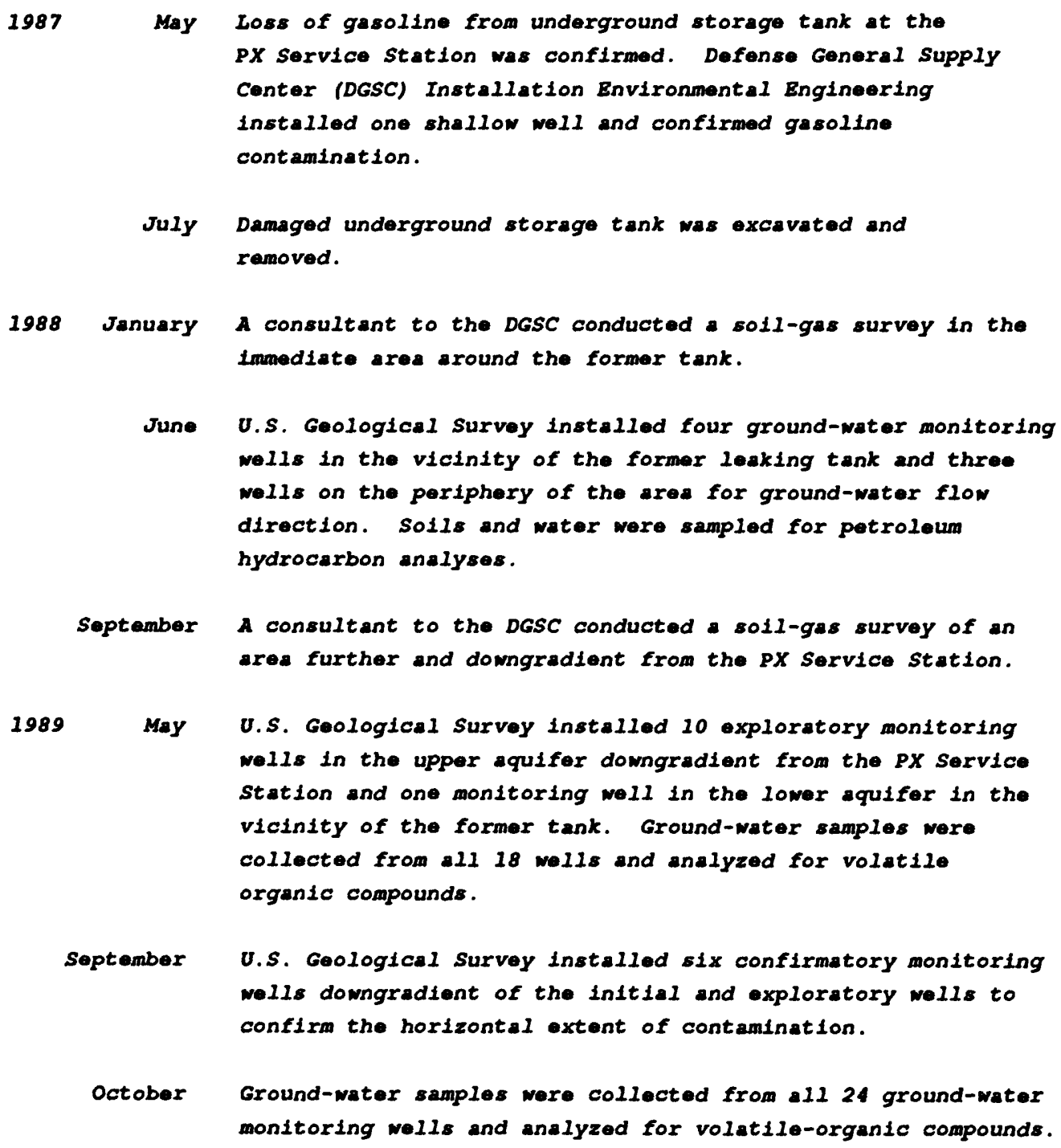




\section{Monitoring-Well Design and Installation}

Twenty-four wells were installed during 1988-89 to define the extent of gasoline contamination (fig. 2). In 1988, four wells were placed in the immediate vicinity of the former tank and three wells were placed on the periphery of the site; these wells were numbered PX-01 through PX-07. In May 1989, a line of five exploratory wells (PX-08 to PX-12) was placed downgradient of the parking lot southeast of the PX Service Station. A second line of five exploratory wells (PX-13 to PX-17) was placed about $300 \mathrm{ft}$ farther downgradient. These exploratory wells were located in an effort to determine the direction of movement of the contaminated ground water. A deep well (PX-01D), penetrating the confining unit and finished in the lower aquifer (Potomac Formation), was installed in the parking lot about 50 ft from the former tank location. In September 1989, six confirmatory wells (PX-18 to 23) were placed downgradient of the initial and exploratory wells to determine the downgradient extent of contamination. Records of the wells installed at the PX Service Station are tabulated in Appendix A.

Wells were installed using the hollow-stem auger drilling method. Each hollow-stem auger had a $67 / 8$-in. (inch) outside diameter and a 4-in. inside diameter. When the first auger flight was drilled down, the chuck was unbolted from the auger flight and raised slightly on the hydraulic slide. A new 5-ft-long section of auger was added by bolting it to the flight of auger already in the ground. The process of drilling $5 \mathrm{ft}$ and then adding a new 5-ft section was continued until the augers encountered the top of the Calvert Formation. A depth of at least $18 \mathrm{ft}$ was required in most cases to reach the bottom of the upper aquifer. Augers were cleaned with a hot-water, high-pressure washer before augering the next hole.

Samples of the unconsolidated sediments were collected while drilling the lower-aquifer well to determine the thickness of the confining unit. Samples were obtained by lowering a hollow-tube sampler through the stem of the augers to the bottom of the hole. A pulley-operated hammer was attached to the pipe and the sampler was hammered two feet into the sediments. The sampler was then removed, and the sample taken from the sampler; drilling then continued. Samples were inspected to indicate whether the sampler had penetrated aquifer or confining-unit material. Samples were also examined for the presence of organic vapors using a portable photoionization detector (PID).

Four wells (PX-02 through PX-05) located in the immediate vicinity of the former tank, and installed by the Survey in June 1988, were constructed of 4-in. inside diameter, flush-threaded polyvinyl chloride (PVC) casing. Three wells on the periphery of the site (PX-01, PX-06, and PX-07) were constructed of 2-in. inside diameter PVC casing. Seventeen wells installed in 1989 were constructed of 2 -in. inside diameter flush-threaded polyvinyl chloride (PVC) well casing.

Well screens were constructed of flush-threaded PVC, 15 to $20 \mathrm{ft}$ long, with $0.010 \mathrm{in}$. slots. Filter sand was poured slowly into the hole to about two feet above the top of the screen. Bentonite pellets were poured into the hole to about three feet above the top of the filter sand. Moisture in the ground causes the bentonite to swell, thereby forming a seal. Grout was inserted, filling the hole from the top of the bentonite seal to the land surface. A 6-in. square by 5-ft long metal security casing was installed over each shallow well, and a 12-in. by 5 - $\mathrm{ft}$ metal security casing was installed over the lower aquifer well. Each security casing was set into concrete. Concrete pads ( 2 -ft by 2 -ft by 4 -in.) were constructed around the security casings. A schematic diagram of the completed wells is shown in figure 8 .

Care was taken to prevent water in the upper aquifer from flowing into the lower aquifer 


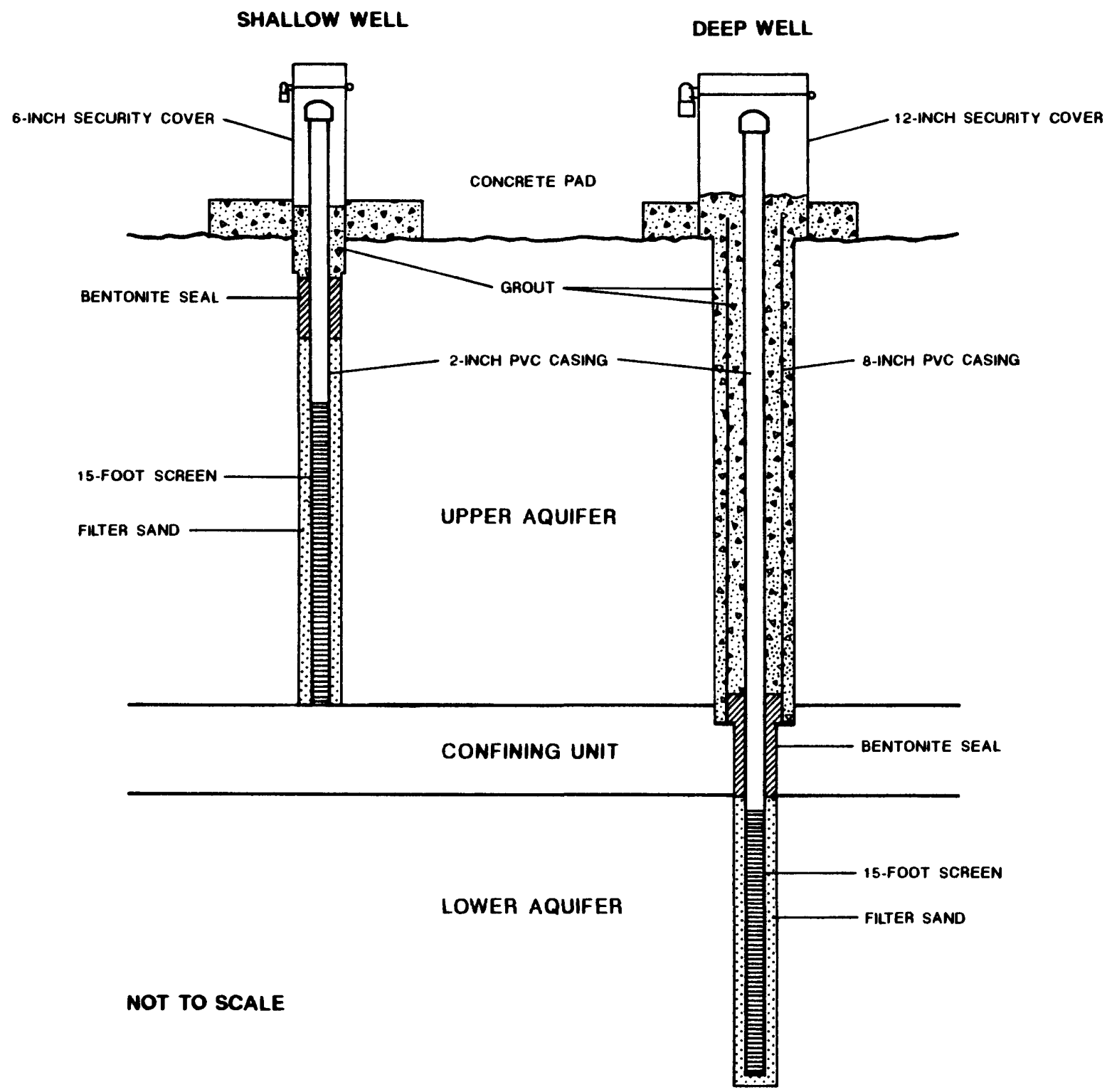

Figure 8.--Construction features of monitoring wells installed at the PX Service Station by the U.S. Geological Survey. 
through the borehole augered through the confining unit. A 10-in. diameter hole was augered to the confining unit and 8-in. inside- diameter PVC casing was pushed to refusal into the confining unit. The annulus between the augered hole and the casing was grouted securely using a tremie pipe and the grout was allowed to harden. Drilling was continued using 6 $7 / 8$-in. diameter augers inside the PVC casing, through the confining unit, and into the lower aquifer. A 2-in. well casing and screen were placed into the lower aquifer through the 8-in. PVC casing. Filter sand was placed around the 15-ft-long screen. Bentonite pellets were poured into the hole filling the annulus was filled from the top of the sand to a depth of 2 $\mathrm{ft}$ above the top of the confining unit. The inside of the 8-in. casing was filled with grout to land surface.

After installation, the monitoring wells were developed by continuously pumping approximately 10 well volumes. Two well volumes were purged from each well prior to collecting a ground-water sample.

\section{Surveying}

Leveling surveys were conducted for each of the wells located at the PX Service Station site to determine accurate land-surface altitudes. Altitudes of measuring points on the wells were surveyed so that the general direction of ground-water flow could be inferred from water-levels referenced to a standard vertical datum.

The altitudes of temporary reference marks at the PX Service Station were determined from a leveling survey from a permanent benchmark located on Interstate Highway 95. In 1986, a leveling survey was conducted from the permanent benchmark to a reference mark located on the DGSC (Powell and others, written commun., 1987). As a part of the effort documented in this report, a leveling survey was then conducted from the reference mark on the DGSC to the temporary reference mark at the PX Service Station.

Health and Safety Plan

A safety plan has been established by the Virginia Office of the U.S. Geological Survey for work assignments in or around hazardous-waste sites. This safety plan includes safety training for all personnel involved in site investigations, maintenance of an exposure data sheet, a periodic medical examination monitoring toxic compounds in the body, and adherence to the wearing of proper field-safety apparel. For work conducted at the PX Service Station, field-safety apparel included splash-proof coveralls, eye protection, rubber gloves, and air-purifying respirators. Hard hats were worn when working around the drilling machine. 


\section{Ground-Water Sampling and Quality-Assurance Program}

In July of 1988, during the initial phase of the assessment program, ground-water samples were collected from the seven initial monitoring wells. In May 1989, ground-water samples were collected from all of the monitoring wells installed to date ( 7 initial wells and 11 exploratory wells). In September and October 1989, ground-water samples were collected from the initial, exploratory, and six confirmatory wells. Temperature, $\mathrm{pH}$, specific conductance, and dissolved-oxygen concentration were measured in the field during all phases. Ground-water samples collected in June 1988 were analyzed for total petroleum hydrocarbons and samples collected in May and September-October 1989 were analyzed for purgeable-organic compounds. The types and dates of ground-water samples, and the field measurements from each well, for the May 1989 sampling are shown in table 3, and results from the September-October 1989 sampling are shown in table 4.

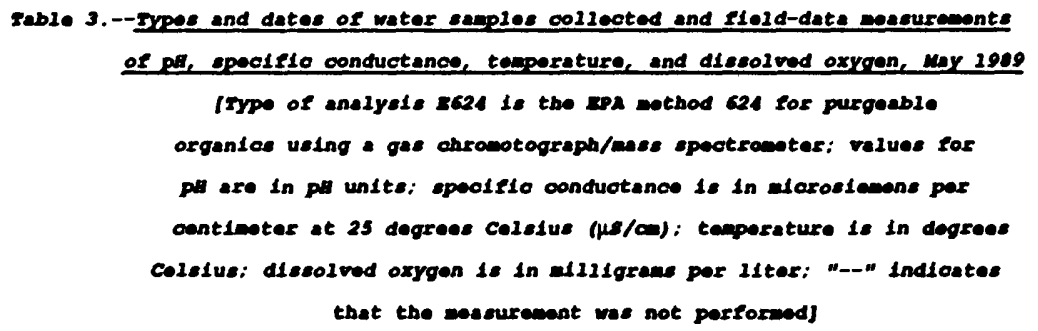

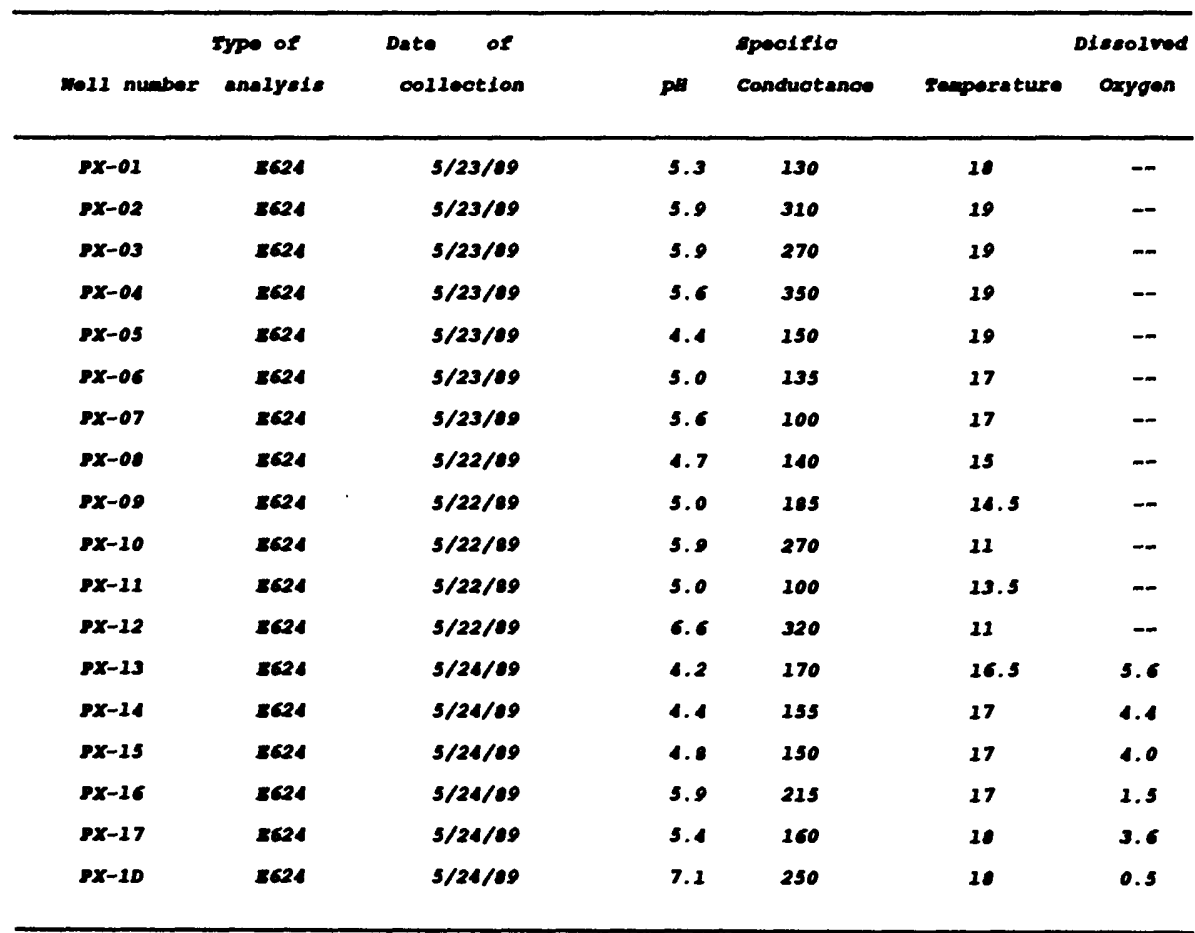




\begin{tabular}{|c|c|c|c|c|c|c|}
\hline \multirow{2}{*}{ Wo22 aumber } & \multicolumn{6}{|c|}{ 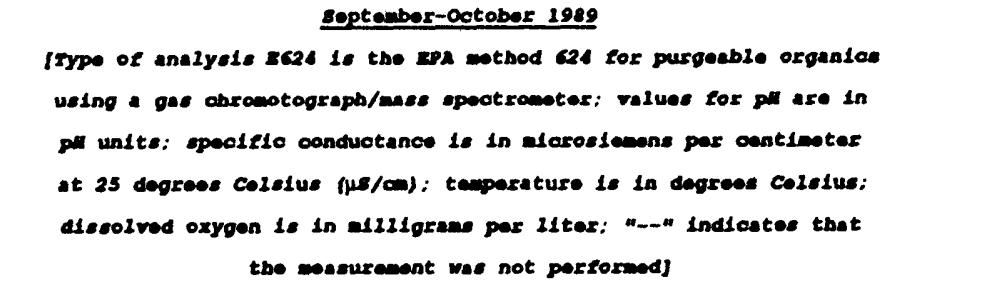 } \\
\hline & Typo of & Date of & & spocifte & & 1esolved \\
\hline$p x-01$ & 8624 & $10 / 23 / 89$ & 4.9 & 150 & 20 & 2.3 \\
\hline $8 x-02$ & 2624 & $10 / 20 / 09$ & 6.2 & 375 & 19 & 0.4 \\
\hline $8 x-03$ & 8624 & $20 / 20 / 09$ & 5.0 & 270 & 29 & .6 \\
\hline $8 x-04$ & 8524 & $20 / 20 / 89$ & 5.7 & 300 & 19 & .4 \\
\hline $8 x-05$ & 8624 & $10 / 20 / 09$ & 5.4 & 220 & 19 & .3 \\
\hline $8 x-06$ & $I 624$ & $10 / 20 / 09$ & 4.9 & 135 & 19 & 1.0 \\
\hline $8 x-07$ & Ic24 & $10 / 23 / e 9$ & 5.7 & $e s$ & 28 & 6.5 \\
\hline $8 x-08$ & 2624 & $10 / 23 / 09$ & 5.1 & 110 & 20 & 6.2 \\
\hline $8 x-09$ & 8524 & $10 / 23 / 09$ & 5.3 & 105 & 29 & 3.0 \\
\hline $8 x-20$ & 8624 & $10 / 20 / 09$ & 5.2 & 110 & 20 & .6 \\
\hline$p x-11$ & 8624 & $10 / 20 / 09$ & 5.0 & 120 & 10 & .7 \\
\hline$p x-12$ & 8624 & $10 / 20 / 09$ & 5.6 & 265 & 10 &.$\bullet$ \\
\hline $5 x-13$ & 8624 & $10 / 23 / 69$ & 4.0 & 175 & 21 & 5.9 \\
\hline$p x-14$ & 8624 & $10 / 23 / 09$ & 4.6 & 244 & 21 & 3.9 \\
\hline$p x-15$ & 8624 & $10 / 23 / 09$ & 5.0 & 160 & 21 & 1.1 \\
\hline $8 x-16$ & 8624 & $10 / 20 / 09$ & 6.3 & 100 & 19 & .5 \\
\hline $8 x-17$ & 2624 & $20 / 20 / 09$ & 6.2 & 375 & 18 & .4 \\
\hline$p x-10$ & $\Sigma 624$ & $9 / 29 / 89$ & 5.3 & 130 & 17 & 7.0 \\
\hline $8 x-19$ & 8624 & $9 / 29 / 89$ & 4.0 & 150 & 10 & 2.3 \\
\hline$p x-20$ & 2624 & $9 / 29 / 09$ & 4.9 & 175 & 19.2 & 1.7 \\
\hline$p x-21$ & 8624 & $9 / 29 / 09$ & 5.7 & 300 & 19. & 5.2 \\
\hline$p x-22$ & 8624 & $9 / 29 / 69$ & 4.7 & 270 & 28 & 2.7 \\
\hline$p x-23$ & 8624 & $9 / 29 / 09$ & 4.9 & 100 & 20.2 & 4.5 \\
\hline$p x-10$ & $\mathbf{E S 2 4}$ & 9/29/e9, $10 / 23 / 09$ & 7.7 & 250 & 27.8 & .3 \\
\hline
\end{tabular}

Prior to sampling each well, the water level in the well was measured to determine the volume of water in the well. The wells were then purged using a positive displacement, air-driven, stainless-steel pump until a minimum of two well volumes (based on borehole diameter) of water had been displaced. Ground-water samples were collected with Teflon ${ }^{\dagger}$ bailers decontaminated between wells. Field measurements of ground-water included temperature, $\mathrm{pH}$, specific conductance, and dissolved-oxygen concentration. The samples were placed in 40-milliliter Teflon-septum vials, preserved with hydrochloric acid to about a $\mathrm{pH}$ of 2 , and immediately chilled on ice. Samples collected each day were stored in ice-filled coolers, provided with a chain-of-custody form, and shipped by overnight delivery to the laboratory.

tUse of brand/trade names in this report is for identification purposes only and does not constitute endorsement by the U.S. Geological Survey. 
Reporting limits are defined as the minimum concentration achieveable for each sample and constiituent, whereas detection limits are the minimum concentration achievable by a laboratory instrument for a particular analytical protocol. Reporting limits are ideally equivalent to detection limits; however, reporting limits are affected by many factors, such as dilution of sample, analytical interferences from target and nontarget parameters, and analytical equipment performance. In addition, reporting limits may vary with the amount of contamination in the sample. For the purposes of this report, results of laboratory analyses for analysis of total petroleum hydrocarbons (USEPA method 418.1) and purgeable-organic compounds (USEPA method 624) are discussed in terms of reporting limits and are presented in table 5.

\begin{tabular}{|c|c|c|}
\hline \multicolumn{3}{|c|}{ 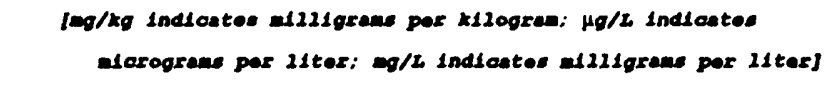 } \\
\hline \multicolumn{2}{|c|}{ noporting 21nit } & onite \\
\hline \multicolumn{3}{|l|}{1012} \\
\hline Total potzoleul bydtocerbone & 50 & $g / x g$ \\
\hline \multicolumn{3}{|l|}{ Ground water } \\
\hline rotal potrol oul hydrocarbona & 0.5 & $\boldsymbol{g} / \boldsymbol{z}$ \\
\hline Coloromotheno & 24 & $\mu g / 2$ \\
\hline Eromomethane & 10 & $\mu g / t$ \\
\hline vingl obloride & 11 & $\mu g / L$ \\
\hline Culorosthane & 20 & $\mu g / L$ \\
\hline Wethylene ohloride & 17 & $\mu g / L$ \\
\hline nowtone & 50 & $\mu g / 2$ \\
\hline carbon dentride & $\mathbf{s}$ & $\mu g / 2$ \\
\hline 1,1-Dichlorouthene & 4 & $\mu \sigma / L$ \\
\hline 2,2-Dlobloroothano & $s$ & $\mu g / 2$ \\
\hline trane-2,2-Diob2orouthene & $s$ & $\mu g / 2$ \\
\hline culororon & $s$ & $\mu g / L$ \\
\hline 1,2-Diobloroethene & 3 & $\mu g / 2$ \\
\hline 2-Butanono & 50 & $\mu \sigma / 2$ \\
\hline 1, 2, 2-rriohlorouthano & $s$ & $\mu \sigma / L$ \\
\hline carbon totracbloride & 3 & $\mu \sigma / 2$ \\
\hline aramodiobloromothane & s & $\mu g / 2$ \\
\hline 1,2-DLabloropropeno & 5 & $\mu g / 2$ \\
\hline trane-1, 3-Dlobloropropene & $s$ & $\mu g / L$ \\
\hline Iriohlorootbene & 3 & $\mu \sigma / 2$ \\
\hline Chlorodibromomothane & 5 & $\mu g / L$ \\
\hline $\begin{array}{l}1,1,2-7 r 10 b \text { loroethene } \\
\text { Eonsene }\end{array}$ & 5 & $\begin{array}{l}\mu g / L \\
\mu g / L\end{array}$ \\
\hline ols-1, 3-Dlabloropropene & 5 & $\mu \sigma / L$ \\
\hline 2-coloroothyl rinyl other & 100 & $\mu g / 2$ \\
\hline aroeofors & 5 & $\mu g / L$ \\
\hline 1-Nethyl-2-pentenone & so & $\mu \sigma / 2$ \\
\hline $1,1,2,2$-7otrachloroothano & 7 & $\mu g / 2$ \\
\hline Totracblorocthene & 3 & $\mu g / L$ \\
\hline roluane & $s$ & $\mu g / 2$ \\
\hline chlorabenzene & 5 & $\mu g / L$ \\
\hline Ethy1 benzene & $s$ & $\mu g / 2$ \\
\hline goted xylenes & $s$ & $\mu g / L$ \\
\hline Srlanlororluoramethane & 20 & $\mu \sigma / 2$ \\
\hline Aarolein & 26 & $\mu g / L$ \\
\hline Morylonitr120 & 10 & $\mu g / 2$ \\
\hline Dibromomothene & 10 & $\mu \sigma / L$ \\
\hline DLoblorodil zuoromothano & 10 & $\mu g / 2$ \\
\hline Ethanol & 50 & $\mu g / 2$ \\
\hline sthyl methacrylate & 10 & $\mu g / 2$ \\
\hline 2-Lexanose & so & $\mu g / 2$ \\
\hline Iodomethane & 20 & $\mu g / L$ \\
\hline atyrene & 3 & $\mu g / 2$ \\
\hline 1,2,3-9r1ohloropropene & 10 & $\mu g / 2$ \\
\hline Viny2 sastate & 50 & $\mu g / 2$ \\
\hline trano-1,1-D1 chloro-2-butano & 30 & $\mu \sigma / 2$ \\
\hline
\end{tabular}


Specific procedures for field-quality assurance for ground-water sampling were designed to verify the sampling methods, shipping integrity, and analytical reproducibility of the laboratory. The types of QA samples collected in the field consist of the following:

1) Duplicate samples from selected wells.-- Duplicate samples were collected from 10 percent of the total number of wells sampled during the assessment program. Collection and analysis of duplicates tests reproducibility within a laboratory.

2) Trip blanks.-- A trip blank was included with every sample-shipping container in order to insure that positive analytical results are not caused by cross-contamination within the sample shipping container or by handling prior to analysis.

3) Ambient-condition blanks.-- Ambient-condition blanks were collected which represent the atmospheric or other field conditions which may affect the analytical results.

4) Equipment blanks.-- Equipment blanks were collected to investigate the possibility of positive analytical results from cross contamination by sampling equipment.

A low concentration of toluene $(6.4 \mu \mathrm{g} / \mathrm{L})$ was reported in the ambient-condition blank collected on May 23, 1989, and may indicate presence of gasoline vapors in the air at the site; therefore, similar low concentrations of BTXs reported in water samples from monitoring wells may be a result of ambient conditions as well.

\section{ASSESSMENT OF GROUND-WATER CONTAMINATION}

The following results are summarized from field investigations and ground-water sampling at the PX Service Station.

\section{Site Assessment}

During this investigation, no free gasoline was observed in the wells at the PX Service Station. Gasoline product was reported in the first well installed near the former tank (W. Saddington, Environmental Engineer, Defense General Supply Center, written commun., 1987).

In July 1988, during the initial phase of the assessment program, ground-water samples were collected from the seven initially-installed monitoring wells. Concentrations of total petroleum hydrocarbons in the ground-water samples were as large as $8.2 \mathrm{mg} / \mathrm{L}$ in the vicinity of the former tank (table 6). Soil samples were collected at 5-ft intervals during drilling of the wells. Analyses of the soil samples indicate concentrations of petroleum hydrocarbons were lower than the reporting limit of $50 \mathrm{mg} / \mathrm{kg}$ (milligrams per kilogram). 
Table 6.--Concentrations of total petroleum hydrocarbons in water

from wells in the vicinity of the former leaking tank,

JulY 1988

[BRL indicates that the concentration was below reporting $1 \mathrm{im}$ it]

\begin{tabular}{ll}
\hline Well no. & $\begin{array}{c}\text { Concentration, in } \\
\text { millgrams per llter }\end{array}$ \\
\hline & \\
PX-01 & BRL \\
PX-02 & 8.2 \\
PX-03 & 2.2 \\
PX-04 & 3.6 \\
PX-05 & 3.3 \\
PX-06 & BRL \\
PX-07 & BRL \\
& \\
\hline
\end{tabular}

Laboratory analyses of ground-water samples from the initial and exploratory wells indicate the presence of large concentrations of purgeable-organic components of gasoline (the BTXs) in the ground water. Results of the laboratory analyses for May 1989 are shown in table 7. Ground-water samples from all wells (initial, exploratory, and confirmatory) were collected and analyzed in September and October 1989; the results of these analyses for BTXs are shown in table 8. The analyses indicate the presence of large concentrations of the purgeable-organic components of gasoline in ground water in the immediate vicinity of the former tank and $500 \mathrm{ft}$ downgradient from the PX Service Station. Concentrations of BTXs in water from the confirmatory wells were below the reporting limit except for $2,300 \mu \mathrm{g} / \mathrm{L}$ of benzene reported in PX-19. Small concentrations of organic compounds other than BTXs were reported in water from the wells (table 9); some of these compounds are gasoline additives. A number of organic compounds were tentatively identified in the water samples from the wells and are listed in table 10 . These tentatively identified compounds were detected by gas chromatograph/mass spectrometer (GC/MS) analysis but are not included in USEPA method 624; these compounds are suspected to be gasoline additives. 
rable 7.--Conoentratione of bonzene, toluene, zylene, and totel bxx oonpounds In water froe welle at the px servioe station, War 1909

(Conountrotione are in morograme por 11ter $(\mu g / L)$; total Brx compounds are the sune of conoontratione of bonzene, toluone, and xylene, in $\mu g / L$ : are indiates oonoentretions below

roporting linlts; in reasks, I Indiastes tentatively

1dentifled oompounde and other oompounds were reported in adation to erx's (ses tables and 10) ]

\begin{tabular}{|c|c|c|c|c|c|}
\hline We11 no. & Denzene & ToLuene & xylene & Fotal Drx & Ranerke \\
\hline$P X-01$ & ane & ane & anc & ER & \\
\hline$P x-02$ & 13,000 & 20,000 & 12,000 & 53,000 & $\mathbf{T}$ \\
\hline$p x-03$ & 17,000 & 25,000 & 11,000 & 53,000 & $\mathbf{T}$ \\
\hline$p x-04$ & 6,200 & 5,000 & 4,000 & 15,200 & $\mathbf{r}$ \\
\hline$p x-05$ & 21,000 & 32,000 & 12,000 & 65,000 & $\boldsymbol{T}$ \\
\hline$p x-06$ & 230 & ene & 140 & 370 & $\mathbf{r}$ \\
\hline$p x-07$ & ens & enes & ens & ens & \\
\hline$P x-00$ & anc & nes & ens & ent & \\
\hline $2 x-09$ & exs & ens & ans & ans & 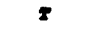 \\
\hline$p x-10$ & 4,100 & 10,000 & 14,000 & 36,100 & $\mathbf{Y}$ \\
\hline$p x-11$ & 4,700 & 11,000 & 6,100 & 22,100 & $\boldsymbol{I}$ \\
\hline$P x-12$ & 25,000 & 43,000 & 15,000 & 03,000 & $\mathbf{T}$ \\
\hline$P x-13$ & are & Der & sar. & ane & $\mathbf{T}$ \\
\hline$p x-14$ & ens & ens & enes & Eer & $\mathrm{r}$ \\
\hline$P x-15$ & 110 & nes & nex & 110 & $\mathbf{F}$ \\
\hline$p x-16$ & 6,900 & 9.900 & 5,000 & 21,800 & $\mathbf{x}$ \\
\hline$p x-17$ & 4,200 & nes & 1,500 & 5,700 & 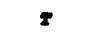 \\
\hline$P X-1 D$ & 0.4 & 10.0 & 15.0 & 41.4 & \\
\hline
\end{tabular}

rable o.--Conoentratione of benzene, toluene, xylone, and total erx compounde In water frae wells at the PX service stetlon, soptember-october 1909

(Conontratione are in alorograme por 11 ter $(\mu g / L)$; total erx compounds are the sune of conoentrations of bonzene, tolueno, and xylene, in $\mu g / 2$; mex indicates conoentrations bolow

roporting linits; in reasiks, I indiates tontetively

ldentilied compounds and other compounde wore reported in addition to erx's (ece tables and 10)]

\begin{tabular}{|c|c|c|c|c|c|}
\hline we11 no. & Eanzene & roluene & xylene & rotal arx & Davarks \\
\hline$p x-01$ & mes & max & שמת & ser. & \\
\hline$P x-02$ & 5,200 & 0,700 & 3,000 & 17,700 & 5 \\
\hline$P x-03$ & 6,900 & 15,000 & 5,200 & 27,100 & $\mathbf{x}$ \\
\hline$P x-04$ & 4,500 & 4,700 & 2,100 & 11,600 & $\mathbf{r}$ \\
\hline$P X-0 S$ & 9,000 & 17,000 & 3,000 & 29,000 & \\
\hline$P X-06$ & 310 & 47 & 69 & 426 & $\mathbf{z}$ \\
\hline$P x-07$ & exe & nes & מns & Ex & \\
\hline$P x-00$ & nes & nes & nes & enes & \\
\hline$P x-09$ & nez & ene & nex & שen & \\
\hline$P x-10$ & 1,100 & 17,000 & 14,000 & 32,100 & 2 \\
\hline$p x-11$ & 5,000 & 9,000 & 5,200 & 20,000 & $\mathbf{T}$ \\
\hline$P x-12$ & 110 & 100 & 100 & 310 & $\mathbf{T}$ \\
\hline$P x-13$ & mez & ext & שes & enc & \\
\hline$p x-14$ & nez & nex & عex & nes & \\
\hline$p x-15$ & 510 & 29 & 51 & 590 & $\mathbf{Y}$ \\
\hline$P x-16$ & 9,700 & 16,000 & 7,900 & 33,600 & $\mathbf{T}$ \\
\hline$p x-17$ & 0,600 & 0,500 & 4,000 & 21,100 & 2 \\
\hline$p x-10$ & ERE & ent & ane & ens & \\
\hline$P x-19$ & 2,300 & ER & $\operatorname{sac}$ & 2,300 & \\
\hline$p x-20$ & anc & ex & שعמ & $\sec$ & \\
\hline$p x-21$ & ERE & ane & ane & are & \\
\hline$p x-22$ & ERE & שas & ans & Exe & 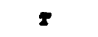 \\
\hline$p x-23$ & ex & nes & exp & eRz & \\
\hline \multirow[t]{2}{*}{$P X-10$} & axe & ang & exs & axe & \\
\hline & gnt & ant. & Dex & שعص & \\
\hline
\end{tabular}


reble 9. --Concentratlone of compounds other then Brx' a Identifled

In watex from wile it the PX servioe station, way 1909

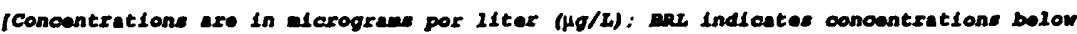
seporting lialts; reporting lialt varies with the enount of contanination in the water.J

mo11 no.

1,1-diohlosoothane Frane-1,2-dioblozoothone Ethyl bonzeno 1,2,3-rriobloropropane carbon disulfide

\begin{tabular}{|c|c|c|c|c|c|}
\hline $5 x-01$ & nax & anc & ERE & nax & axe. \\
\hline $8 x-02$ & Ber & anz & anc & mex & $\operatorname{anc}$ \\
\hline $8 x-03$ & ars & ane & ans & ane & arc \\
\hline$p x-04$ & ane & ane & 820 & anz & anz \\
\hline$P x-05$ & BaE & ans & anz & sas & $\operatorname{anc}$ \\
\hline$P x-06$ & Bar & anz & ane & anes & Des \\
\hline $8 x-07$ & sere & $\sec$ & $\operatorname{sex}$ & ane & are \\
\hline$P x-00$ & ane & ane & nes & anc & and \\
\hline$p x-00$ & 31.0 & 7.9 & ane & anz & and \\
\hline$p x-10$ & $\operatorname{anz}$ & ser. & 2,600 & anz & mer \\
\hline $8 x-11$ & Dre & nex & 1,100 & mer & ane \\
\hline$P x-12$ & anz & ane & 2,900 & nex & nex \\
\hline$p x-13$ & 13.0 & 12.0 & ane & anc & nes \\
\hline$p x-14$ & 23.0 & ane & anz & nex & mex \\
\hline$P x-25$ & 26.0 & 17.0 & $\operatorname{anc}$ & ane & ses \\
\hline$p x-26$ & ser & and & 1,100 & ane & $\sec$ \\
\hline$P x-17$ & nez & anz & 400 & 4,100 & anc \\
\hline$p x-18$ & max & $\max$ & ex & ser & nRE \\
\hline$p x-19$ & nex & nes & ees & anz & max \\
\hline$P x-20$ & nez & ans & anz & anz & anz \\
\hline$P x-21$ & ser & arL & sRz & nex & anc \\
\hline$p x-22$ & nes & anz & nat & ens & 18.0 \\
\hline$P x-23$ & mex & and & anes & nes & ans \\
\hline$P x-10$ & sex & mer & mex & $\operatorname{anz}$ & max \\
\hline
\end{tabular}

rable 10.--compounde tentatively identified in water froe welle at the px serviae station

[Fantatively idantified oompounds are those not inoludod in rea sotbod 621]

Compound tentatively idantified

Nootanide, M-Nothy2-

Eenzone, 1,3, 3-geimothyleutane

buteno, 2-Mothy1-

Cyolopantano

Propane, 2-wthozy-2-wothyl-

1-propone, 2-wothyl- 
Contaminants that could not be attributed to the gasoline contamination were reported in water from some wells in the upper aquifer. These compounds (1,1-dichloroethene and trans-1,2-dichloroethene, shown in table 9) are solvents and were reported in water from wells PX-09, $-13,-14$, and -15 from the May 1989 sampling round. The reporting limits of the compounds for these analyses were $5,5,5$, and $10 \mu \mathrm{g} / \mathrm{L}$, respectively. Reporting limits differ with the amount of contamination in the water. Analyses of water from wells with large concentrations of BTXs required high reporting limits for all of the compounds in that particular sample. Therefore, large concentrations of BTXs in particular wells may mask the presence of smaller concentrations of solvents in water from those wells. The extent of low concentrations of organic-solvents in the ground water cannot be determined with the data available. Carbon disulfide reported in water from well PX-22 may be derived from an insecticide (Merck Index, 1983).

Total BTX concentrations (or the sum, in micrograms per liter, of each of the concentrations of the individual compounds--benzene, toluene, and xylene) in water from wells at the PX Service Station from the May 1989 sampling indicate the areas where the greatest contamination occurs (fig. 9). Detectable concentrations of total BTXs reported in water from wells in the upper aquifer in May 1989 range from 370 to $83,000 \mu \mathrm{g} / \mathrm{L}$. Confirmatory wells were sited on the basis of results shown in figure 9.

Analytical results of total BTXs in water from all wells, including the confirmatory wells, for September-October 1989 are shown in figure 10. Concentrations of contaminants in the ground water remained relatively large in the immediate vicinity of the former tank and $600 \mathrm{ft}$ downgradient from the tank. Concentrations of total BTXs in water from some wells showed increases, and concentrations in water from other wells showed decreases. Concentrations of contaminants in wells PX-16 and PX-17 increased from 21,800 and $5,700 \mu \mathrm{g} / \mathrm{L}$ to 33,600 and $21,100 \mu \mathrm{g} / \mathrm{L}$, respectively. The most notable change is the decrease in concentrations in well PX-12, where BTX concentrations decreased from $83,000 \mu \mathrm{g} / \mathrm{L}$ in May 1989 to $310 \mu \mathrm{g} / \mathrm{L}$ in September-October 1989. A duplicate water sample from PX-12 showed a similar decrease. Changes in concentrations of contaminants, such as in wells PX-12, PX-16, and PX-17, indicate the transient nature of the zone of ground-water contamination within the upper aquifer.

Detectable concentrations of benzene in water from contaminated wells in the upper aquifer range from 112 to $9,700 \mu \mathrm{g} / \mathrm{L}$ for the September-October 1989 sampling (fig. 11). Because of the large concentration of benzene in water from well number PX-19, there is a possibility that the contaminant plume extends farther downgradient than well PX-19. Detectable concentrations of toluene in water from contaminated wells in the upper aquifer range from 29 to $17,000 \mu \mathrm{g} / \mathrm{L}$ for the September-October 1989 sampling (fig. 12). Detectable concentrations of total xylenes in water from contaminated wells in the upper aquifer range from 51 to 14,000 $\mu \mathrm{g} / \mathrm{L}$ for the September-October 1989 sampling (fig. 13).

Assuming that the removed storage tank was the source of contaminants reported, that the zone of contamination does not extend much further downgradient than well number PX-19, and that the contamination has moved within the ground water in the upper aquifer at the estimated rate of about 60 to $80 \mathrm{ft}$ per year, the contaminants appear to have been introduced into the upper aquifer as long as 7 to 10 years ago. The removed tank may have been leaking much longer than presumed or other tanks and spills in the area may be sources of contamination.

Organic vapors were detected in samples of the aquifer material collected at $5-\mathrm{ft}$ depth intervals during installation of the lower-aquifer well, indicating that the confining unit and lower aquifer might be contaminated. Samples were placed into glass jars and allowed to 

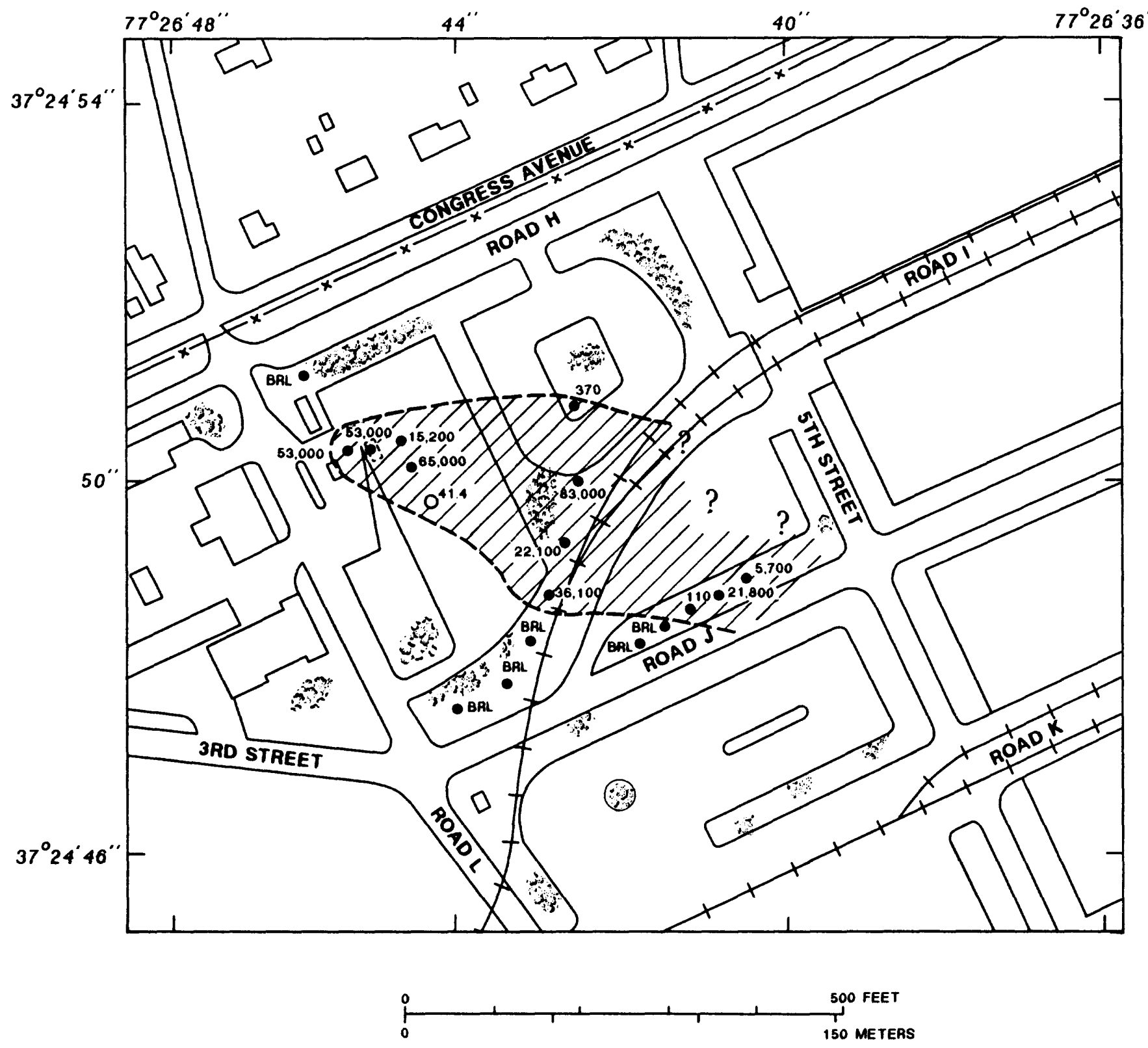

EXPLANATION INFERRED AREA OF CONTAMINATION IN UPPER AQUIFER BASED ON BTXs
ABOVE REPORTING LIMIT

- UPPER AQUifer Well location

O LOWER AQUIFER WELL LOCATION

21.800 CONCENTRATION OF BTXs, IN MICROGRAMS PER LITER

BRL CONCENTRATION OF BTXS BELOW REPORTING LIMIT

Figure 9.--Concentrations of total benzene, toluene, and xylenes (BTXs) in water from wells at the PX Service Station, May 1989. 

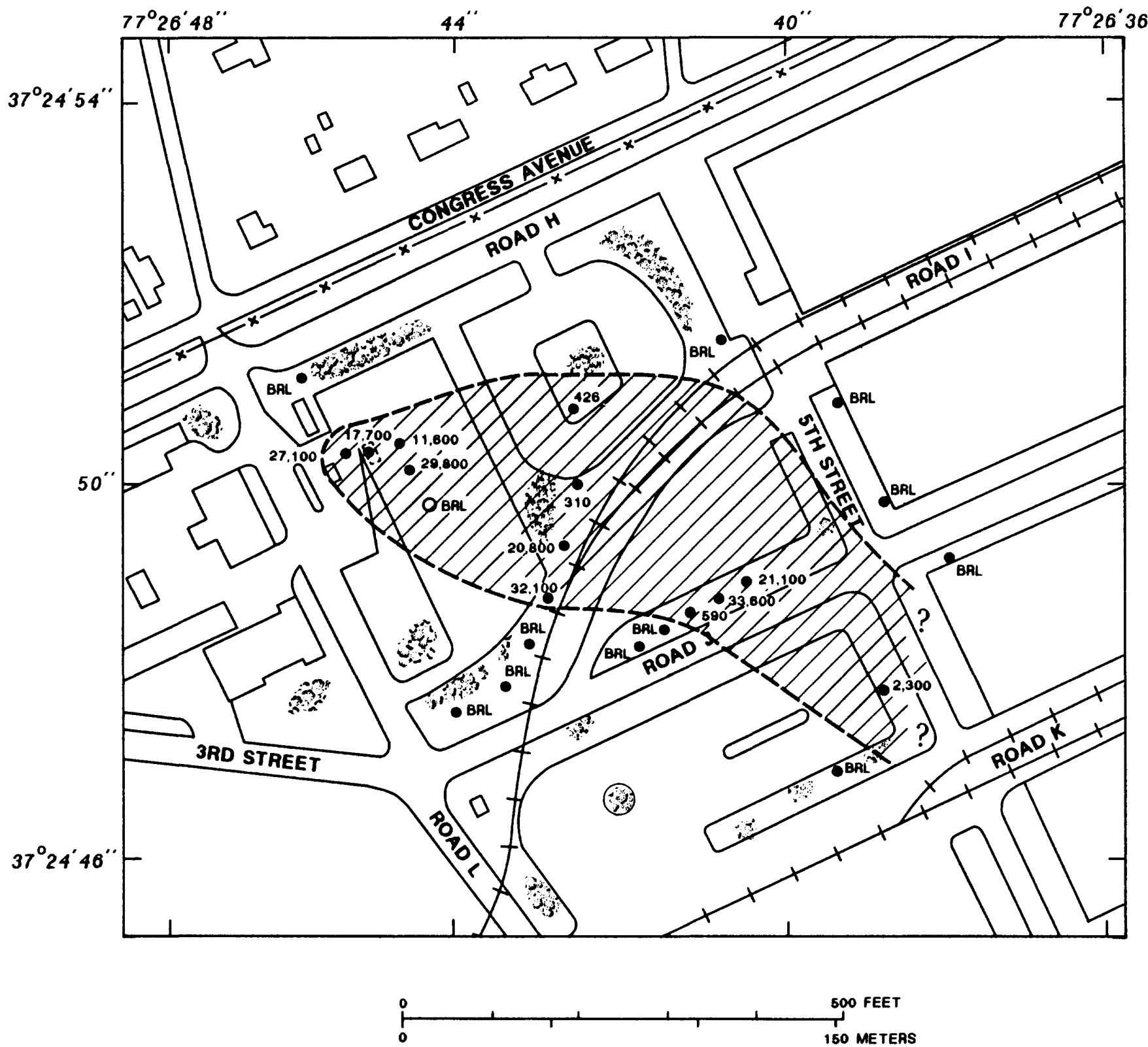

EXPLANATION

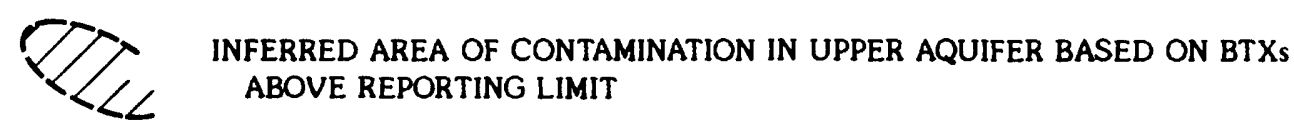

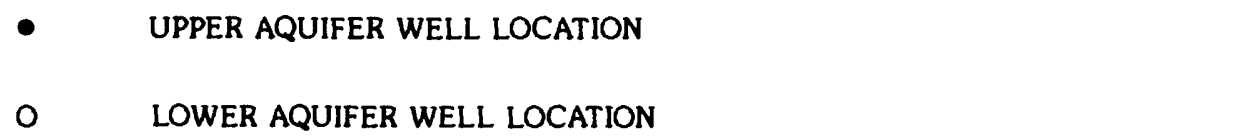

27.100 CONCENTRATION OF BTXs, IN MICROGRAMS PER LITER

BRL CONCENTRATION OF BTXS BELOW REPORTING LIMIT

Figure 10.--Concentrations of total benzene, toluene, and xylenes (BTXs) in water from wells at the PX Service Station, September-October 1989. 

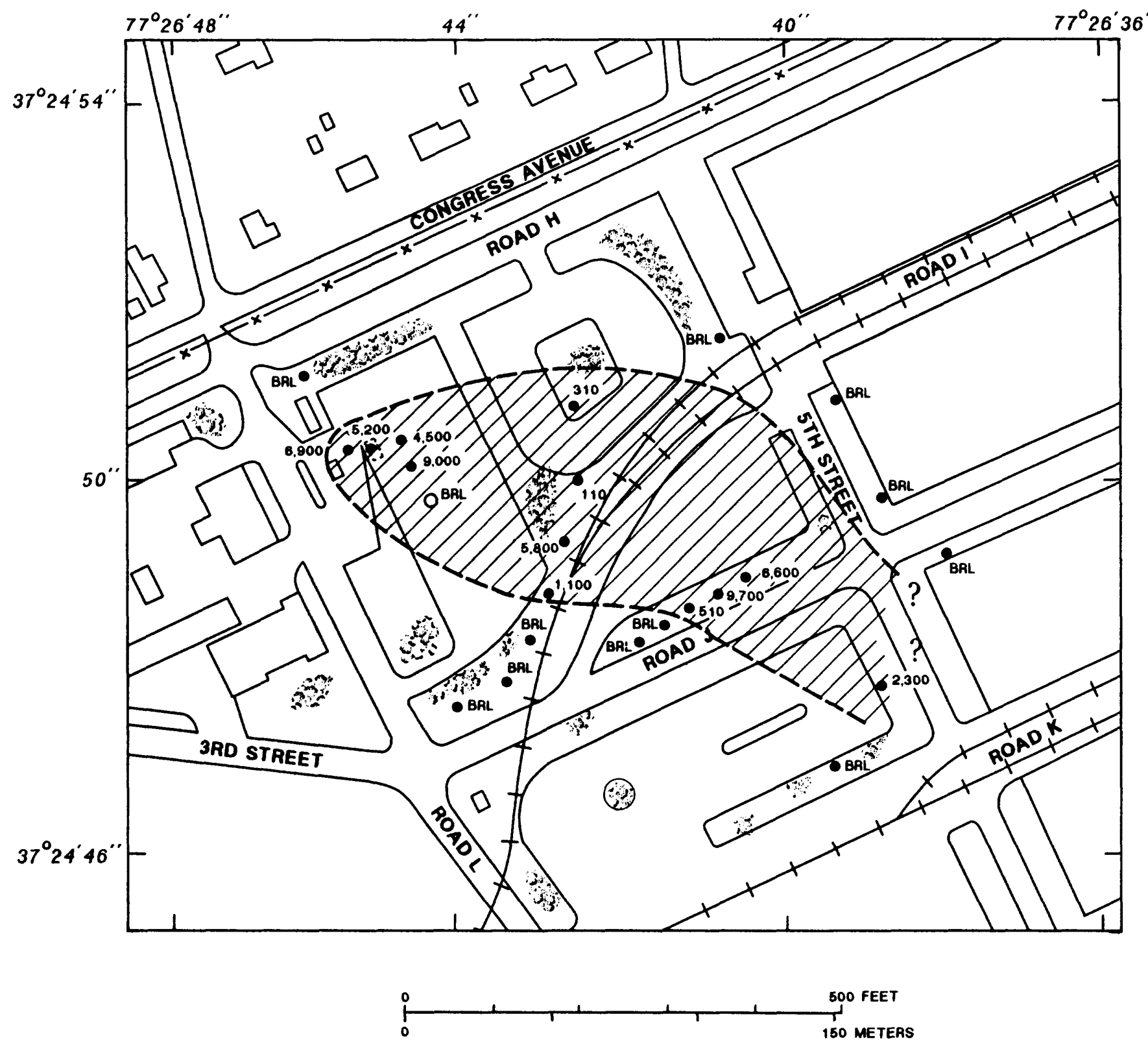

\section{EXPLANATION}

INFERRED AREA OF CONTAMINATION IN UPPER AQUIFER BASED ON BENZENE
CONCENTRATIONS ABOVE REPORTING LIMIT

- UPPER aQUifer Well location

O LOWER AQUIFER WELL LOCATION

6.200 CONCENTRATION OF BENZENE, IN MICROGRAMS PER LITER

BRL CONCENTRATION OF BENZENE BELOW REPORTING LIMIT

Figure 11.--Concentrations of benzene in water from wells at the PX Service Station, September-October 1989. 

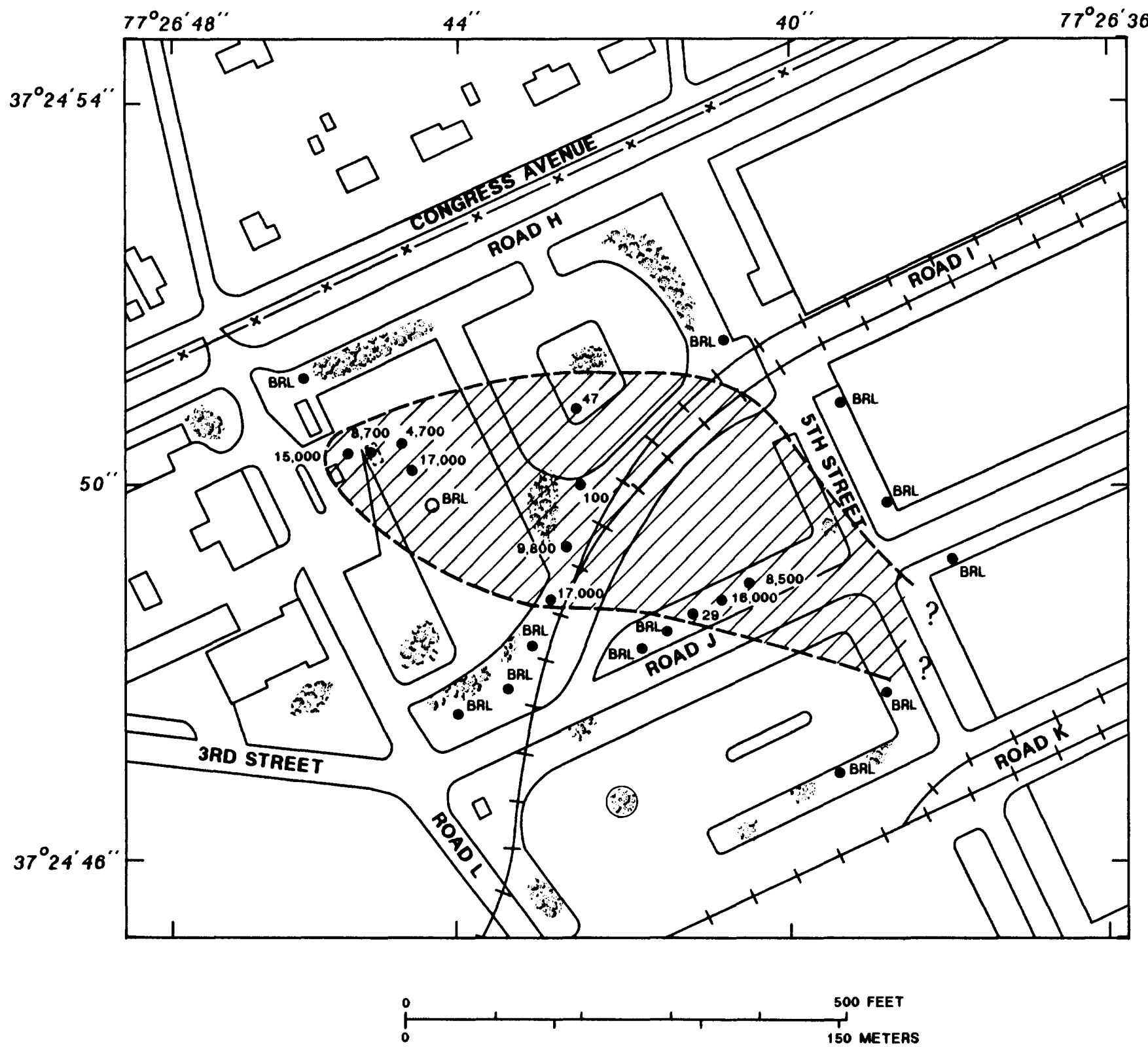

EXPLANATION INFERRED AREA OF CONTAMINATION IN UPPER AQUIFER BASED ON TOLUENE
CONCENTRATIONS ABOVE REPORTING LIMIT

- UPPER AQUifer Well location

O LOWER AQUIFER WELL LOCATION

15.000 CONCENTRATION OF TOLUENE, IN MICROGRAMS PER LITER

BRL CONCENTRATION OF TOLUENE BELOW REPORTING LIMIT

Figure 12.--Concentrations of toluene in water from wells at the PX Service Station, September-October 1989. 

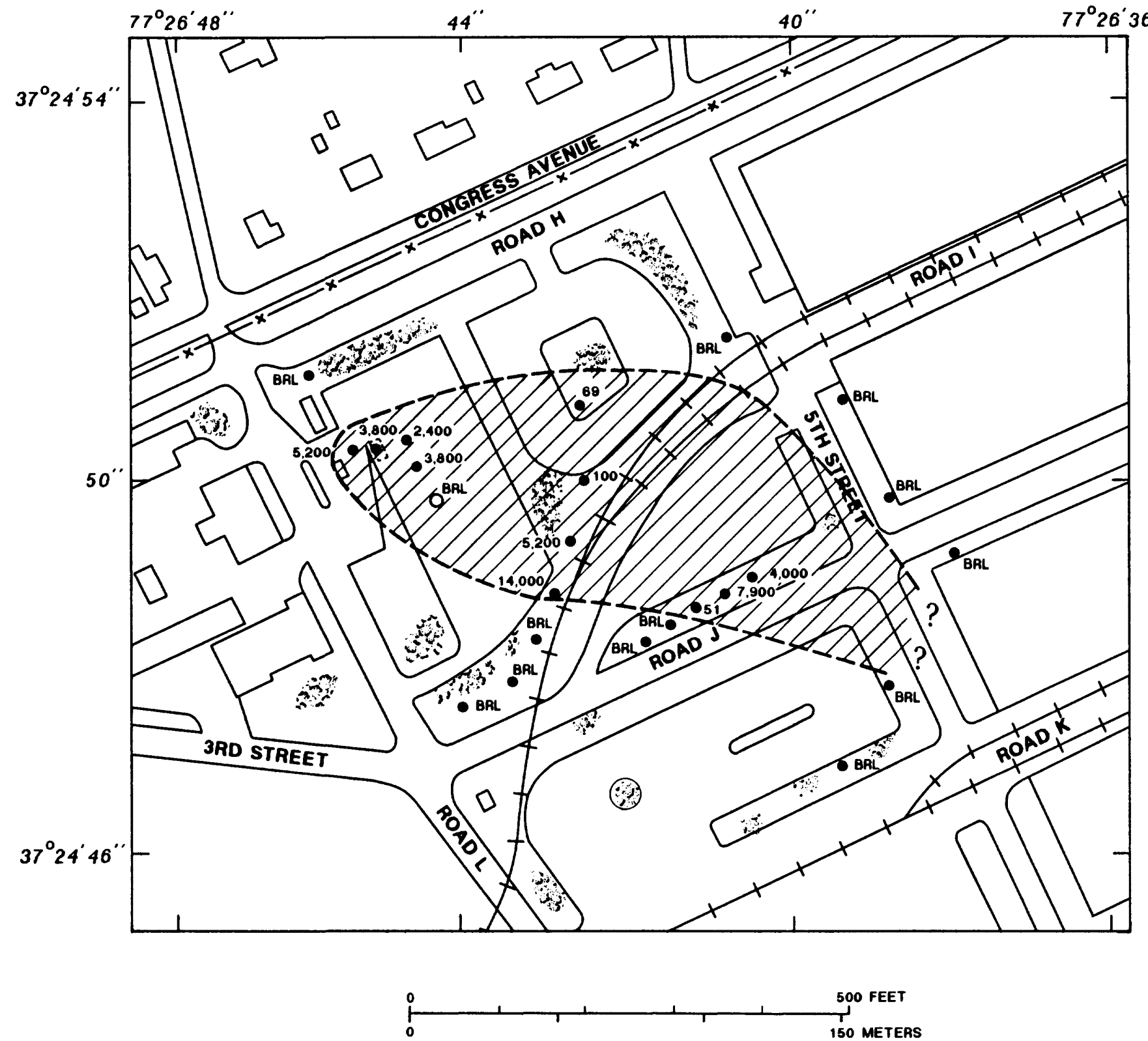

EXPLANATION

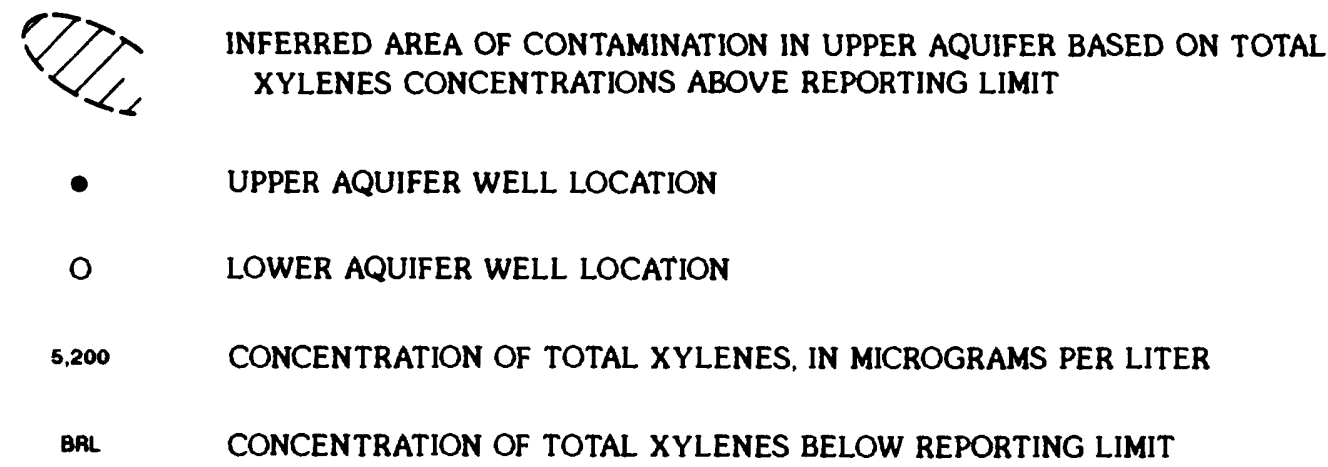

Figure 13.--Concentrations of total xylenes in water from wells at the PX Service Station, September-October 1989. 
sit for about 5 minutes; then, the relative concentrations of organic vapors were measured with a field- photoionization detector (PID) zeroed to ambient air. Organic vapors were detected in large concentrations (relative to ambient air) in the bottom of the upper aquifer and in the top of the confining unit. Organic vapors also were detected in the samples collected deeper in the confining unit and into the lower aquifer but the relative concentrations were much lower. These organic vapors, although not identified by composition, are probably constituents of gasoline, indicating the presence of contamination in the confining unit and lower aquifer. These data indicate that this confining unit, comprised of silt and clay, may not prevent transport of organic contaminants in ground water.

Laboratory analyses of water samples from the lower-aquifer well do not conclusively indicate whether the lower aquifer is contaminated with constituents of gasoline. One of three water samples collected from the lower aquifer contained detectable concentrations of constituents of gasoline. Total BTX concentrations in water from the lower aquifer from the May 1989 sampling were $41.4 \mu \mathrm{g} / \mathrm{L}$. Concentrations of BTXs in the lower aquifer were below reporting limits, however, for the second and third samples of water collected from the lower-aquifer well on September 29, 1989, and October 23, 1989. The causes for the variations in the analytical results are not known. Ranges of concentrations of contaminants in the lower aquifer and the extent of contamination, if present, cannot be determined without installation of additional wells and analysis of additional ground-water samples.

\section{Risk Assessment}

The purpose of risk assessment is to determine the likelihood of negative effects on human or wildlife populations due to exposure to hazardous materials. This report provides a preliminary assessment of risk to support the examination of (1) the plausibility of a no action alternative, or (2) the need for remedial action. Suggestions for further studies are also identified.

The purgeable-organic compounds benzene, toluene, and xylene were selected as indicator chemicals for evaluating risk through time and for monitoring the effectiveness and progress of plausible remedial alternatives. These compounds, major constituents of gasoline, are present in large concentrations in many of the ground-water monitoring wells at the site; benzene is considered a carcinogen to humans (Sax, 1984).

Available data indicate that there probably are no human receptors of the contaminated ground water. Most, if not all, of the privately owned wells in the vicinity of the DGSC have been tested because of the potential for contamination from previously-studied sites; those wells were not contaminated by BTXs and are no longer used for private drinking-water supply.

For this report, the maximum contaminant levels (MCLs) and proposed maximum contaminant level goals (MCLGs) defined for the contaminants detected are used as applicable standards for the assessment of the degree of contamination. MCL, as defined by the USEPA (U.S.

Environmental Protection Agency, 1986), is the maximum permissible level of a contaminant in water which is delivered to any user of a public-water system; MCL is an enforceable standard. MCLG is a non-enforceable concentration of a drinking-water contaminant that is protective of adverse human health effects and allows an adequate margin of safety. The MCL and MCLGs for the chemical constituents of concern at the PX Service Station are shown in table 11. 


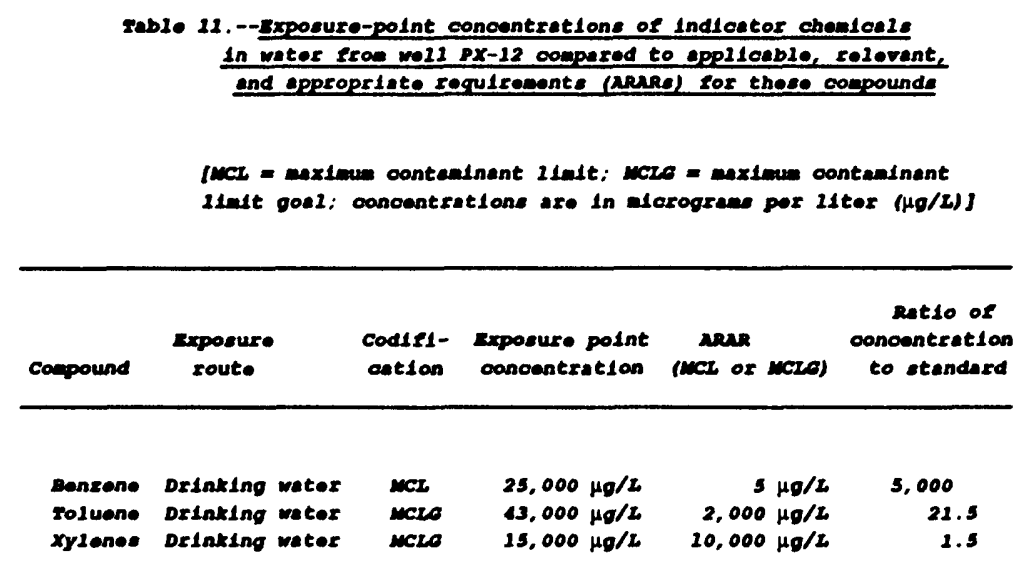

A qualitative risk for future potential receptors can be presented using the MCL and MCLGs as applicable, appropriate, and relevent requirements (ARARs) for drinking water. The concentrations of benzene, toluene, and xylenes in water from well PX-12 exceed the MCL and MCLGs by factors of 5,000,21.5, and 1.5, respectively (table 11). Risk to potential receptors is assumed when concentrations exceed MCLs and remedial actions to reduce the risk of exposure to benzene are appropriate; however, sufficient data are not available to assess the areal extent and concentrations of benzene in the ground water downgradient from the existing ground-water monitoring wells. Assessment of risk from exposure to ground-water contamination in the lower aquifer cannot be addressed with the few data that are available to date.

There is no apparent danger to wildlife living in the area of known ground-water contamination associated with the PX Service Station. In addition, there are no known endangered species of wildlife within the known area of contamination. The possibility of contaminants infiltrating the storm sewers and discharging into Kingsland Creek cannot be thoroughly evaluated given the data available.

\section{Remediation Assessment}

If the upper and lower aquifers are considered to have no potential as a source of drinking water (no future receptors), then the appropriate remedial action could be the no-action alternative. If the concern is to attain concentrations that are allowable lifetime exposure concentrations in order to protect future potential receptors, remedial action could be undertaken to obtain concentrations equal to or less than the ARARs.

Purposes of remedial action would be the prevention of further downgradient movement of the contamination plume, prevention of downward vertical movement of contamination into the lower aquifer, removal of contamination in the dissolved phase in the plume, and location and removal of possible free product. Three alternatives are possible approaches to remediation of the ground-water contamination at the PX Service Station. These alternatives are:

1) No action.

2) Installation of soil-vapor extraction pumps on existing monitoring wells and in gravel-filled remediation trenches for evaporation of purgeable-organic compounds from ground water and extraction of purgeables from the unsaturated zone.

3) Pumping of ground water from subsurface drains and treatment of the water using air-stripping towers. 
The no-action alternative represents the situation in which remedial actions are not undertaken. This alternative would not reduce concentrations of contaminants in the ground water and would allow contaminants to continue to migrate along present pathways. The primary justification for selection of this alternative is that there are no known human receptors for the contaminated ground water, and limiting hydrogeologic conditions (such as the shallow water-bearing zone in the upper aquifer) preclude the efficient application of remedial actions.

Soil-vapor extraction has been shown to be an effective method for remediating ground water contaminated by purgeable-organic compounds (Baehr and others, 1989). Movement of vapors through the unsaturated zone by air pumps creates concentration gradients between the contaminants in the ground water and the vapor phase of the contaminants in the unsaturated zone; therefore, contaminants evaporate into the unsaturated zone and are removed by the air pumps. Air pumps can be installed on existing ground-water monitoring wells (2-inch and 4-inch wells) in the zones of largest contamination; this removes the contaminants from the saturated and unsaturated zones where it is most needed. Air pumps can be quickly installed on monitoring wells to begin remediation; however, the optimal design capacities of the air pumps need to be determined through additional investigations, such as conducted by Baehr and Hult (1989). Advantages of the soil-vapor extraction method are that it is not dependent on the thickness of the water-bearing zone in the upper aquifer, it will function during dry seasons, it does not require disposal of effluent, and it can be immediately implemented pending more detailed investigations. Disadvantages of this method are that it does not immediately block movement of contamination towards the storm sewer and wet seasons may negatively affect soil-vapor movement.

The third alternative includes pumping and treating contaminated ground water from subsurface drains. The purposes of the ground-water pumping from subsurface drains could be to (1) intercept the downgradient movement of the contamination plume, (2) reverse the gradient of the water table downgradient of the drain to capture the leading edge of the contamination plume, and (3) remove and treat the contaminated ground water (U.S. Environmental Protection Agency, 1985, p. 5-47). Ground-water extraction and development of a drawdown trough in the upper aquifer may be difficult because the thickness of the water-bearing zone in the upper aquifer ranges from about 4 to 7 feet (fig. 6). In addition, the contamination plume is so widespread that remediating the entire plume by ground-water pumping would be inefficient. Advantages of the ground-water pumping method are that it can be immediately implemented pending further studies of hydraulic conductivities at the PX Service Station and it could remove the contaminated ground water. Disadvantages are that it requires disposal of effluent, may not operate well in dry seasons or in the shallow water-bearing zone of the upper aquifer, and may not remove contaminants which have adsorbed onto aquifer material in the unsaturated zone.

Implementation of a combination of the above methods might be the most effective approach to remediate the ground-water contamination at the PX Service Station. Soil-vapor extraction can be implemented by (1) installing air pumps on monitoring wells in the zones of highest concentrations, and (2) installing a gravel-filled infiltration trench for ground-water pumping upgradient of the storm sewer. Additional ground-water monitoring wells are needed to monitor the progress of remediation and to improve descriptions of the extent and possible other sources of the contamination, including the source of the solvent contaminants. Continued sampling for ground-water contaminants in water from wells at the PX Service Station is needed to verify the water-quality results presented in this report. Remediation of the lower aquifer cannot be evaluated without additional sampling and water analyses and hydraulic-head data from the lower aquifer. 
It is possible that gasoline product remains in the vicinity of the former leaking tank but not in the location of the monitoring wells near the tank. This lens, or zone of gasoline product, if present, needs to be located and removed to fully address remediation, otherwise the gasoline product will continue to function as a source for ground-water contamination. Further investigations are required to verify the occurrence of gasoline product in ground water at the site.

\section{SUMMARY AND CONCLUSIONS}

The U.S. Geological Survey installed 24 monitoring wells in a Coastal Plain multiple-aquifer/confining-unit system to collect and analyze ground-water samples for the presence of gasoline contamination in the vicinity of the PX Service Station at the DGSC, near Richmond, Virginia. Seven initial wells were installed in May 1988 and sampled in June 1988; 11 exploratory wells were installed and sampled in May 1989; and 6 confirmatory wells were installed in September 1989. All of the wells were sampled in September-October 1989.

The initial ground-water monitoring wells were sampled in June 1988 for total petroleum hydrocarbons. Laboratory analyses of water from the wells reported the presence of large concentrations of petroleum hydrocarbons (ranging from 2 to $8 \mathrm{mg} / \mathrm{L}$ ). Laboratory analyses of soil samples collected during drilling indicated small concentrations of petroleum hydrocarbons in the soil--concentrations lower than the reporting limit of $50 \mathrm{mg} / \mathrm{kg}$.

The exploratory monitoring wells were sampled in May 1989 and water from the wells was analyzed for the purgeable-organic compounds. Concentrations of BTXs reported in water from wells in the upper aquifer were as large as $83,000 \mu \mathrm{g} / \mathrm{L}$. The largest concentrations are found in the immediate vicinity of the former leaking tank and about 600 feet southeast from the site. BTXs in small concentrations of 8 and $18 \mu \mathrm{g} / \mathrm{L}$ were reported in water from the lower-aquifer well from the May 1989 sampling; however, results of analyses of water samples from the lower aquifer collected in September and October 1989 indicated that the concentrations of these contaminants were below reporting limits.

All of the upper-aquifer wells ( 23 wells consisting of the initial, exploratory, and confirmatory wells) were sampled in September-October 1989. Concentrations of BTXs in water from these wells remained large in the immediate vicinity of the former tank and $500 \mathrm{ft}$ downgradient from the PX Service Station. Concentrations of BTXs in water from the confirmatory wells were low and below reporting limits.

Low concentrations of solvents were reported in water from several of the monitoring wells downgradient from the PX Service Station. The source of these solvents probably is not related to the former leaking tank.

No floating gasoline was observed in the wells at the site; however, gasoline product was reported when the leak was first discovered. Because it is possible that gasoline product remains in the ground near the former leaking tank, an investigation to determine this would be worthwhile. Additional ground-water monitoring wells are needed west of the PX Service Station to determine whether contamination is entering the site from the west.

Samples of materials from the confining unit, collected while installing the lower-aquifer well, were examined for the presence of organic vapors using a field photoionization detector. Organic vapors were detected in the samples from differing depths throughout the confining unit indicating that this silty-clay confining unit might not prevent the downward movement of organic compounds in ground water. Laboratory analyses of water samples from the lower-aquifer well, however, do not conclusively indicate that the lower aquifer is contaminated with constituents derived from gasoline. 
Ground water in the upper aquifer moves to the east-southeast; the rate of ground-water flow in the upper aquifer in the vicinity of the PX Service Station is approximately $60-80 \mathrm{ft}$ per year. Available ground-water analytical data suggest that the contaminant plume is oriented along the direction of ground-water flow in the upper aquifer; however, the extent of the plume is not well defined. The thickness of the water-bearing zone in the upper aquifer averages about $5.5 \mathrm{ft}$ in the study area. The storm sewers, where constructed below the water table, may collect and conduct ground water from the upper aquifer to Kingsland Creek. The lower aquifer is an unconfined aquifer in the vicinity of the PX Service Station; north of the site, data indicate it is a confined aquifer. The direction and rate of ground-water flow in the lower aquifer is not known because only one well taps the lower aquifer in the vicinity of the study area.

The greatest horizontal extent of contamination was reported in a well located $600 \mathrm{ft}$ downgradient from the PX Service Station where the benzene concentration was 2,300 $\mu \mathrm{g} / \mathrm{L}$. Assuming that the removed storage tank was the source of contaminants reported, that the zone of contamination does not extend much farther downgradient than well number PX-19, and that the contamination has moved within the ground water in the upper aquifer at the estimated rate of about 60 to $80 \mathrm{ft}$ per year, the contaminants were probably introduced into the upper aquifer as long as 7 to 10 years ago. The removed tank had probably been leaking much longer than thought, or other tanks and spills in the area may have been sources of contamination.

Preliminary risk assessment for the site identified no potential receptors nor pathways of exposure for the contamination. However, the largest concentrations of contaminants at the site exceed the USEPA MCL and MCLGs and the concentration of benzene in the most contaminated wells exceeds the MCL for benzene by a factor of 5,000; therefore, remediation may be necessary if risk to future potential receptors is a concern.

Alternatives discussed for remediation of ground-water contamination in the upper aquifer at the PX Service Station include the no action, soil-vapor extraction from existing monitoring wells by air pumps, and ground-water pumping and treatment from gravel-filled subsurface drains. The most favorable remedial action appears to be is a combination of soil-vapor extraction and ground-water pumping and treatment. Implementation of any method will require additional studies to determine the effects of remediation on ground-water quality.

Suggestions for further studies include--

1) Verification of the occurrence of gasoline product in the ground near the former leaking tank.

2) Performance of aquifer tests at the PX Service Station to improve accuracy of estimates of hydraulic conductivity and ground-water velocity.

3) Installation of additional monitoring wells to investigate possible sources other than the known former leaking tank and to improve definition of the vertical and horizontal extent of contamination, especially downgradient of well number PX-19 and to the north and south of the PX Service Station.

4) Investigation of air permeabilities of the unsaturated zone (if the soil-vapor extraction method is selected) for design of air-pump capacities.

5) Continued sampling to verify the results presented in this report and to monitor the effectiveness of remediation. 


\section{REFERENCES}

Alexander, M., 1981, Biodegradation of chemicals of environmental concern: Science, v. 211, p. 128-132.

Baehr, A.L., Hoag, G.E., and Marley, M.C., 1989, Removal of volatile contaminants from the unsaturated zone by inducing advective air-phase transport: Journal of Contaminant Hydrology, v. 4, no. 1, p. 1-26.

Baehr, A.L., and Hult, M.F., 1989, Determination of the air-phase permeability tensor of an unsaturated zone at the Bemidji, Minnesota, research site, in Mallard, G.E., and Ragone, S.E., eds., U.S. Geological Survey toxic substances program-- Proceedings of the technical meeting, Phoenix, Arizona, September 26-30, 1988: U.S. Geological Survey Water-Resources Investigations Report 88-4220, p. 55-62.

Callahan, M.A., 1979, Water-Related Environmental Fate of 129 Priority Pollutants: EPA-4401 4-79-029 a and b (2 v.), U.S. Environmental Protection Agency, Washington, D.C.

Cherry, J.A., Gillham, R.W., and Barker, J.F., 1984, Contaminants in groundwater-- chemical processes, in Groundwater Contamination, National Academy Press, Washington, D.C., p. 46-64.

Chiou, C.T., Kohnert, R.L., Freed, V.H., and Tonkyn, R.G., 1983, Predictions of evaporative loss rates of solutes in stagnant and turbulent waters in relation to rates of reference materials: Environment International, v. 9, p. 13-17.

Meng, A.A., III, and Harsh, J.F., 1988, Hydrogeologic framework of the Virginia Coastal Plain: U.S. Geological Survey Professional Paper 1404-C, 82 p.

Merck Index, The, 1983: Merck \& Co., Inc., Rahway, N.J., U.S.A., 1,463 p.

Sax, N.I., 1984, Dangerous Properties of Industrial Materials: Van Nostrand Reinhold Company, New York, New York, 3,124 p.

Target Environmental Services, 1988a, Soil-gas survey, post exchange service station, Defense General Supply Center, Richmond, Virginia: Target Environmental Services, Inc., Columbia, Maryland, $17 \mathrm{p}$.

1988b, Phase II, soil-gas survey, post exchange service station, Defense General Supply Center, Richmond, Virginia: Target Environmental Services, Columbia, Maryland, $20 \mathrm{p}$.

U.S. Environmental Protection Agency, 1985, Handbook - Remedial Action at Waste Disposal Sites (Revised): EPA/625/6-85/006.

1986, Maximum contaminant levels (subpart B of part 141, National primary drinking-water regulations): U.S. Code of Federal Regulations, Title 40, parts 100 to 149, revised July 1, 1986: U.S. Environmental Protection Agency, Washington, D.C., p. 524-528. 
Appendix A.--Records of wells at the Defense General Supply Center PX Service Station

[Depth of well is in feet below land surface; casing material "P"

indicates polyvinyl chloride (PVC); diameter of casing is in inches;

length of screen is in feet; altitude of measuring point, where the

measuring point is the top of the well casing, is in feet above

sea level]

\begin{tabular}{|c|c|c|c|c|c|c|c|c|c|c|}
\hline $\begin{array}{c}\text { Well } \\
\text { number }\end{array}$ & $\frac{\text { Latitud }}{\text { degrees }}$ & $\frac{d e}{\operatorname{minu}}$ & $\frac{\text { Lon }}{\text { utes }}$ & $\frac{\text { ngitude }}{\text { seconds }}$ & $\begin{array}{l}\text { Depth } \\
\text { of well }\end{array}$ & $\begin{array}{c}\text { Casing } \\
\text { material }\end{array}$ & $\begin{array}{l}\text { Diameter } \\
\text { of } \\
\text { casing }\end{array}$ & $\begin{array}{l}\text { Length } \\
\text { of } \\
\text { screen }\end{array}$ & $\begin{array}{l}\text { Altitude } \\
\text { of measuring } \\
\text { point }\end{array}$ & $\begin{array}{l}\text { Date } \\
\text { of } \\
\text { construction }\end{array}$ \\
\hline $\begin{array}{l}P X-01 \\
P X-02 \\
P X-03 \\
P X-04 \\
P X-05 \\
P X-06 \\
P X-07 \\
P X-08 \\
P X-09 \\
P X-10 \\
P X-11 \\
P X-12 \\
P X-13 \\
P X-14 \\
P X-15 \\
P X-16 \\
P X-17 \\
P X-18 \\
P X-19 \\
P X-20 \\
P X-21 \\
P X-22 \\
P X-23 \\
P X-1 D\end{array}$ & $\begin{array}{ll}37 & 24 \\
37 & 24 \\
37 & 24 \\
37 & 24 \\
37 & 24 \\
37 & 24 \\
37 & 24 \\
37 & 24 \\
37 & 24 \\
37 & 24 \\
37 & 24 \\
37 & 24 \\
37 & 24 \\
37 & 24 \\
37 & 24 \\
37 & 24 \\
37 & 24 \\
37 & 24 \\
37 & 24 \\
37 & 24 \\
37 & 24 \\
37 & 24 \\
37 & 24 \\
37 & 24\end{array}$ & $\begin{array}{ll}51 & 0 \\
51 & 0 \\
51 & 0 \\
51 & 0 \\
51 & 0 \\
51 & 0 \\
51 & 0 \\
51 & 0 \\
51 & 0 \\
51 & 0 \\
51 & 0 \\
51 & 0 \\
49 & 0 \\
49 & 0 \\
49 & 0 \\
49 & 0 \\
49 & 0 \\
48 & 0 \\
48 & 0 \\
48 & 0 \\
48 & 0 \\
49 & 0 \\
49 & 0 \\
51 & 0\end{array}$ & $\begin{array}{l}0772 \\
0772 \\
0772 \\
0772 \\
0772 \\
0772 \\
0772 \\
0772 \\
0772 \\
0772 \\
0772 \\
0772 \\
0772 \\
0772 \\
0772 \\
0772 \\
0772 \\
0772 \\
0772 \\
0772 \\
0772 \\
0772 \\
0772 \\
0772 \\
0772\end{array}$ & $\begin{array}{ll}26 & 44 \\
26 & 44 \\
26 & 44 \\
26 & 44 \\
26 & 44 \\
26 & 44 \\
26 & 44 \\
26 & 42 \\
26 & 42 \\
26 & 42 \\
26 & 42 \\
26 & 42 \\
26 & 43 \\
26 & 43 \\
26 & 43 \\
26 & 43 \\
26 & 43 \\
26 & 42 \\
26 & 42 \\
26 & 42 \\
26 & 42 \\
26 & 42 \\
26 & 42 \\
26 & 44\end{array}$ & $\begin{array}{l}20.0 \\
19.0 \\
19.0 \\
19.0 \\
19.0 \\
20.0 \\
19.0 \\
18.0 \\
18.0 \\
23.0 \\
21.0 \\
21.0 \\
23.0 \\
23.0 \\
23.0 \\
25.0 \\
23.0 \\
23.0 \\
23.0 \\
13.0 \\
13.0 \\
13.0 \\
13.0 \\
52.0\end{array}$ & $\begin{array}{l}P \\
P \\
P \\
P \\
P \\
P \\
P \\
P \\
P \\
P \\
P \\
P \\
P \\
P \\
P \\
P \\
P \\
P \\
P \\
P \\
P \\
P \\
P \\
P\end{array}$ & $\begin{array}{l}2.0 \\
4.0 \\
4.0 \\
4.0 \\
4.0 \\
2.0 \\
2.0 \\
2.0 \\
2.0 \\
2.0 \\
2.0 \\
2.0 \\
2.0 \\
2.0 \\
2.0 \\
2.0 \\
2.0 \\
2.0 \\
2.0 \\
2.0 \\
2.0 \\
2.0 \\
2.0 \\
2.0\end{array}$ & $\begin{array}{l}10.0 \\
15.0 \\
15.0 \\
15.0 \\
15.0 \\
10.0 \\
10.0 \\
10.0 \\
15.0 \\
15.0 \\
10.0 \\
10.0 \\
15.0 \\
15.0 \\
15.0 \\
10.0 \\
15.0 \\
15.0 \\
15.0 \\
10.0 \\
10.0 \\
10.0 \\
10.0 \\
15.0\end{array}$ & $\begin{array}{l}130.7 \\
128.0 \\
128.0 \\
128.7 \\
128.6 \\
128.7 \\
128.2 \\
123.9 \\
124.3 \\
125.2 \\
126.3 \\
127.2 \\
127.3 \\
127.6 \\
128.3 \\
129.0 \\
129.1 \\
129.6 \\
129.2 \\
123.1 \\
123.5 \\
123.9 \\
123.8 \\
130.1\end{array}$ & $\begin{array}{l}06 / 28 / 88 \\
06 / 29 / 88 \\
06 / 29 / 88 \\
06 / 29 / 88 \\
06 / 29 / 88 \\
06 / 28 / 88 \\
06 / 28 / 88 \\
05 / 12 / 89 \\
05 / 12 / 89 \\
05 / 12 / 89 \\
05 / 12 / 89 \\
05 / 12 / 89 \\
05 / 13 / 89 \\
05 / 13 / 89 \\
05 / 13 / 89 \\
05 / 15 / 89 \\
05 / 15 / 89 \\
09 / 21 / 89 \\
09 / 22 / 89 \\
09 / 22 / 89 \\
09 / 22 / 89 \\
09 / 22 / 89 \\
09 / 22 / 89 \\
05 / 14 / 89\end{array}$ \\
\hline
\end{tabular}

